\title{
Genomic approach in evaluating the role of androgens on the growth of Atlantic cod (Gadus morhua) previtellogenic oocytes
}

\author{
Trond M. Kortner ${ }^{\text {a }}$, Eduardo Rocha ${ }^{\text {b,c }}$, Paula Silva ${ }^{\text {b,c }}$, L. Filipe C. Castro ${ }^{\text {, }}$, Augustine Arukwe ${ }^{\text {a,* }}$ \\ a Department of Biology, Norwegian University of Science and Technology (NTNU), Høgskoleringen 5, 7491 Trondheim, Norway \\ b Laboratory of Histology and Embryology, ICBAS-Institute of Biomedical Sciences Abel Salazar, University of Porto, Portugal \\ c Laboratory of Cellular and Molecular Studies, CIIMAR-Interdisciplinary Centre for Marine and Environmental Research, Porto, Portugal
}

\section{A R T I C L E I N F O}

\section{Article history:}

Received 1 February 2008

Received in revised form 14 April 2008

Accepted 15 April 2008

Available online 23 April 2008

\section{Keywords:}

Previtellogenic oocytes

Androgens

Atlantic cod

Targeted array

Histology

Reproductive endocrinology

\begin{abstract}
A B S T R A C T
Previous studies have suggested that androgens may play an integral role in early oocyte development in fish. This study evaluated the effects of androgens (11-ketotestosterone: 11-KT and testosterone: T) on gene expression patterns and growth of cod previtellogenic oocytes. cDNA libraries of androgen-responsive genes were generated using suppressive subtractive hybridization (SSH) of clones containing differentially expressed genes in oocytes separately exposed to different concentrations of 11-KT and T, in addition to a solvent control. Secondly, a targeted microarray was developed based on differentially expressed genes. In the experimental setup, tissue was cultured in vitro with different concentrations of $11-\mathrm{KT}$ and $\mathrm{T}(0,10$ and $100 \mu \mathrm{M})$. The array analyses showed 0.5-3.5-fold significant alterations in transcript levels for a number of genes. Real-time PCR and in -situ hybridization were also used to analyze the changes in expression for selected genes. Quantitative histological analyses showed a consistent stereological validation of oocyte growth and development after exposure to androgens. The present study reveals novel roles of androgens on the development of previtellogenic oocytes, suggesting androgen control of early oocyte growth in cod. The strong effects of 11-KT on oocyte growth support our hypothesis that non-aromatizable androgens may exert direct hormonal effects in previtellogenic oocytes, with possible consequences for overt fecundity.
\end{abstract}

(C) 2008 Elsevier Inc. All rights reserved.

\section{Introduction}

Prior to vitellogenesis (previtellogenesis), androgens are suggested to play an integral role in the regulation of oocyte growth and development. Preliminary evidence supporting these assumptions are derived from the induction of oocyte growth in androgen exposed immature female eels (Rohr et al., 2001). It has been demonstrated that 11-ketotestosterone (11-KT, the active male-specific androgen in teleosts) induces growth (increase in oocyte diameter) and development of previtellogenic eel oocytes both in vitro and in vivo (Lokman et al., 2007; Rohr et al., 2001). Generally, androgens appear to play a pivotal role in stimulating the growth of small ovarian follicles in vertebrates, at least in mammals and fish (Rohr et al., 2001; Weil et al., 1999, 1998). In mammals, androgens also modify the intra-ovarian gene expression, as demonstrated by increased mRNA abundance of insulin-like growth factor-1 (IGF-1) and IGF-1-receptor (Vendola et al., 1999) in follicles up to early antral stage. The role of androgens in previtellogenic oocytes is supported by the observation that the early ovarian growth of species-specific critical stage progressed in hypophysectomized freshwater turtle, Chrysemys picta, indicating that gonadotrophins were not necessary (Ho et al., 1982).

\footnotetext{
* Corresponding author. Tel.: +47 73 596265; fax: +47 73591600. E-mail address: arukwe@bio.ntnu.no (A. Arukwe).
}

Furthermore, Bieniarz and Kime (1986) were unable to demonstrate specific binding of radio labeled $\mathrm{GtH}\left({ }^{125} \mathrm{I}-\mathrm{GtH}\right)$ to previtellogenic common carp (Cyprinus carpio) ovaries. Except for the evidence that androgens increase oocyte diameter and modify growth factor mRNA abundance, the underlying molecular mechanism(s) involved in possible regulation of genes whose functional products modulate the growth of previtellogenic oocytes has not been investigated.

Oviparous vertebrates lay yolky eggs that provide necessary nutrients for embryonic development. Oogenesis is an integral aspect of reproduction that comprises a multi-step process resulting in egg laying and can be divided into previtellogenesis, vitellogenesis and final oocyte maturation (Tyler and Sumpter, 1996). The fish ovary consists of numerous ovigerous folds extending from the ovarian wall towards the centre of the ovary. The oogonia are formed by mitosis in the vicinity of the luminal epithelium, and are recognized as small nests of mitotic cells dispersed within the ovary connective tissue. Oogenesis commences when oogonia are transformed into previtellogenic oocytes, and each oocyte is simultaneously surrounded by a follicular cell envelope (Kjesbu and Kryvi, 1989). Final maturation transforms small primary oocytes in meiotic prophase into large yolky haploid eggs ready for ovulation and fertilization (Caussanel and Breuzet, 1977). Oogenesis in Atlantic cod has previously been investigated (Dahle et al., 2003; Kjesbu and Kryvi, 1989; Kjesbu et al., 1996) and these studies mainly focused on the vitellogenic process. 
Thus, what is known today about previtellogenesis in cod (and teleosts in general) is in sharp contrast with the knowledge regarding the processes of vitellogenesis and final oocyte maturation (Tyler and Sumpter, 1996). The endocrine system plays a major role in controlling oogenesis in oviparous vertebrates. Gonadotropins secreted from the pituitary gland finally stimulate the ovarian production of steroids hormones (estrogens), which in turn mediate the vitellogenic process. Final oocyte maturation is mediated by progesterone-derivatives (Chan et al., 1978). During the previtellogenic phase, the oocytes of a typical teleost fish may increase at least 10 -fold in diameter (from about $10-150 \mu \mathrm{m}$ and above $150 \mu \mathrm{M}$ ). An extensive synthesis of RNA, mRNA coding for vitellogenin (Vtg)-receptor, accumulation of mitochondria, polyribosomes, lipids and cortical alveoli are all characteristics of previtellogenesis (Mommsen and Walsh, 1988). In addition, the formation of the zona radiata and ovarian follicle are integral aspects of early oocyte growth (Abraham et al., 1984). Despite the fact that these changes are integral and critical processes in oogenesis, essentially nothing is known about their endocrine and/or physiological control in the early stages. Given that fecundity seems to be largely determined during previtellogenesis in response to nutritional cues in rainbow trout (Bromage et al., 1992; MacKenzie et al., 1998), this still represents a strong gap in our knowledge of fish endocrine and reproductive physiology.

Like in other vertebrates, testosterone $(\mathrm{T})$ is present in female teleost fish. In addition, the non-aromatizable androgen 11-ketotestosterone (11-KT) is usually present, and generally believed to be the most potent androgen in teleosts (Borg 1994; Lokman et al., 2002). Despite that 11-KT is generally believed to be the active male-specific androgen in teleosts, it has been found at elevated levels in some female teleosts (Leatherland et al., 1982; Slater et al., 1994). However, aromatizable (T) and nonaromatizable (11-KT) androgens may have strikingly different effects (Borg 1994). Androgens mediate their actions by binding to specific receptors belonging to the steroid hormone receptor super-family. Androgen receptor (AR) isoforms have been identified in several teleosts (Ikeuchi et al., 1999; Takeo and Yamashita, 1999; Todo et al., 1999; Touhata et al., 1999). ARs are usually located in the nucleus, and have normally high binding affinities for either T or $5 \alpha$-dihydrotestosterone (DHT) (Sperry and Thomas, 1999a,b, 2000). Recently, a nuclear androgen receptor activated by 11-KT was characterized (Olsson et al., 2005). Despite the significance of these findings for fish reproductive physiology, the above mentioned studies did not describe exactly the roles or effects of androgens in the fish ovary. We believed that the identification of androgen-responsive genes and the characterization of specific gene expression patterns due to androgen stimulation of fish oocytes will provide a better understanding of the internal signals that control fecundity in teleosts.

Therefore, we have used the analytical power of suppressive subtractive hybridization (SSH) with subsequent development of a targeted cDNA gene array (CodArray) to open a possible revealing window in understanding the functional aspects of androgen effects on oocyte growth and development, and we present the identification of a number of androgen-responsive genes in the previtellogenic cod ovary. SSH, sequencing of cod androgen-responsive previtellogenic ovarian genes and expression profiling studies represent a potentially important scientific and practical approach for developing an efficient hormonal control of fecundity in the aquaculture industry (especially for new species) and fishery stock management.

\section{Materials and methods}

\subsection{Chemicals and reagents}

Testosterone $(\mathrm{T})$ was purchased from Fluka chemika-biochemika (Buchs, Switzerland) and 11-ketotestosterone (11-KT) was kindly provided by Dr Bente Nilsen (Biosense Laboratories AS, Norway). Trizol reagent for RNA purification, TA cloning kit, Leibovitz L-15 medium and
Superscript III cDNA synthesis kit were purchased from Gibco-Invitrogen life technologies (Carlsbad, CA, USA). Bovine serum albumin (BSA) and $N$-[2-hydroxyethyl]piperazine- $N^{\prime}$-[2-ethanesulfonic acid] (Hepes) were purchased from Sigma Chemical (St. Louis, MO, USA). Iscript cDNA Synthesis Kit and $\mathrm{iTaq}^{\mathrm{TM}} \mathrm{Sybr}{ }^{\circledR}$ Green supermix with ROX were purchased from Bio-Rad laboratories (Hercules, CA, USA) and Generuler ${ }^{\mathrm{TM}} 100$ bp DNA ladder and dNTPs from Fermentas GmbH (Germany). RNA later, sodium salt citrate (SSC) and sodium dodecyl sulfate (SDS) washing solutions were purchased from Ambion (Austin, TX, USA), Oligotex mRNA kit from Qiagen (Valencia, CA, USA), MultiScreen-PCR96 filter plates from Millipore (Billerica, MA, USA) and 3DNA array 350 microarray kit from Genisphere (Hatfield, PA, USA). Amicon YM30 columns were purchased from Millipore (Volketswil, Switzerland). 11KT enzyme immunoassay (EIA) kit (Cat. No. 582751) was purchased from Cayman Chemical Company (Ann Arbor, MI, USA). All other chemicals were of the highest commercially available grade.

\subsection{Animals and floating agarose in vitro culture technique}

Juvenile, previtellogenic female Atlantic cod (Gadus morhua, Gadidae), 150-350 g body mass were purchased from Akvaforsk Genetic Centre (Sunndalsøra, Norway) and kept in circulating water at $10{ }^{\circ} \mathrm{C}$ and $12: 12 \mathrm{~h}$ light:dark photoperiod. The organ culture technique employed was based on the in vitro agarose floating method, which has successfully been used previously in our laboratory for related studies on cod and Atlantic salmon gonadal tissues (Kortner and Arukwe, 2007a,b; Vang et al., 2007). Briefly, juvenile female cod were anesthetized, sacrificed and washed in $70 \%$ ethanol. Ovaries were removed, cut into small pieces $(1 \times 1 \times 1 \mathrm{~mm})$ and grown in 6 -well dishes on a floating agarose substrate covered with a nitrocellulose membrane in basal culture media. The basal culture medium consisted of Leibovitz L-15 medium supplemented with $0.1 \mathrm{mM} \mathrm{L}-$ glutamate, $0.1 \mathrm{mM}$ L-aspartate, $1.7 \mathrm{mM}$ L-proline, $0.5 \% \mathrm{BSA}$, and $10 \mathrm{mM}$ HEPES ( $\mathrm{pH}$ 7.4). The gonadal tissue was cultured randomly in triplicates $(n=3)$ for 5 and 10 days with different concentrations of testosterone and $11-\mathrm{KT}(0$ (control), 10 and $100 \mu \mathrm{M})$ in a humidified incubator at $10{ }^{\circ} \mathrm{C}$. The control group received ethanol (carrier vehicle for the androgens) and the final concentration of ethanol in all exposure groups was $0.3 \%(\mathrm{v} / \mathrm{v})$. The medium was changed every 5 days after sampling at days 5 and 10 of exposure. After cultivation, tissues for RNA purification were homogenized directly in Trizol reagent and stored at $-80{ }^{\circ} \mathrm{C}$ until further processing. Tissues for histological analyses were placed in tissue cassettes with a nylon mesh and fixed in $4 \%$ paraformaldehyde.

\subsection{Production of substracted cDNA library}

We generated a targeted cDNA library by performing suppressive subtractive hybridization ( $\mathrm{SSH}$ ) with ovary tissue from juvenile Atlantic cod exposed separately to $11-\mathrm{KT}$ and $\mathrm{T}(1,50$ and $100 \mu \mathrm{M})$ and used against untreated samples (solvent control samples). Tissues were incubated in vitro as described above, with cultivation for 7 and 14 days. After 7 and 14 days of exposure, samples were collected and transferred to RNA later. The total RNA was isolated using phenol: chloroform, and messenger RNA (mRNA) was purified from total RNA using an Oligotex mRNA kit and used for subtractive hybridization. The SSH experiment was performed in the forward and reverse directions to obtain up-regulated and down-regulated genes, respectively. Subtractive hybridizations were constructed using the Clontech (Palo Alto, CA, USA) SSH kit following the manufacturer's protocol. The SSH was performed by EcoArray Inc. (Alachua, FL, USA) under contract. Sequenced clones were analyzed using Blastx against the NCBI nonredundant (nr) protein database and Blastn against the NCBI nucleotide (nt) database. The chosen e-value cut-off was $10^{-5}$ for blast searches. Finally, clones were annotated and downloaded to the NCBI GenBank EST database under the title CodArray SSH cDNA library. 


\subsection{Array spotting}

The cod gonadal cDNA array (CodArray) was constructed using clones with expression patterns that were either up- or downregulated in the subtracted library. However, SSH generated a number of redundant clones in the subtracted amplicons, and several genes suspected to be involved in the transcriptional regulation of oocyte growth and development were not represented after performing $\mathrm{SSH}$ in the present study. Therefore, transcripts for some genes (e.g. steroidogenic acute regulatory protein (StAR), cytochrome P450mediated side-chain cleavage (P450scc) and cyclin-B) were amplified by PCR using specific primers from conserved regions of the respective genes based on sequence information in NCBI GenBank. The PCR products were cloned into Escherichia coli plasmids and subsequently added to the array. All clones were PCR amplified, verified by agarose gel electrophoresis and then purified using MultiScreen-PCR96 Filter Plates. Clones were diluted in 50\% DMSO buffer and spotted onto Corning Ultragaps glass slides (humidity: $50 \%$, temperature: $18{ }^{\circ} \mathrm{C}$ ) and cross-linked by UV radiation $(800 \mathrm{~mJ})$. The printing service was provided by the Norwegian Microarray Consortium (NMC) at the National Technology Platform supported by the functional genomics programme (FUGE) of the Norwegian Research Council (NFR).

\subsection{RNA purification and $C D N A$ synthesis}

Total RNA was purified from tissues homogenized in Trizol reagent according to established procedures. Quantification, purity and RNA integrity were evaluated by absorbance at 260 and $280 \mathrm{~nm}$ using a NanoDrop ${ }^{\circledR}$ ND-1000 UV-Visible Spectrophotometer (NanoDrop Technologies, Wilmington, DE, USA) and agarose gel electrophoresis. High quality RNA with A260/A280 ratio above 1.8 and intact ribosomal 28S and 18S RNA bands was used for CDNA synthesis. Total cDNA for the realtime polymerase chain reaction (PCR) were generated from $1 \mu \mathrm{g}$ total RNA from all samples using a mixture of random and poly-T primers from iScript cDNA synthesis kit as described by the manufacturer (BioRad). Prior to quantification each cDNA sample was diluted 1:6.

\subsection{Probe labelling and hybridization}

Hybridization of the array was performed using Cy5/Cy3-labeled cDNA probes. cDNA probes were generated using $5 \mu \mathrm{g}$ total RNA from the respective exposure conditions in triplicates $(n=3)$ using Superscript III cDNA synthesis kit as described by the manufacturer (Invitrogen) and $1 \mu \mathrm{L}$ Cy 5 or Cy3 RT primers, $1 \mu \mathrm{L}$ dNTPs, $2 \mu \mathrm{L}$ of $0.1 \mathrm{M}$ DTT and $1 \mu \mathrm{L}$ of RNAse inhibitor using 3DNA Array 350 microarray kit (Genisphere) for each reaction. cDNA probes were generated by incubating samples for $1 \mathrm{~h}$ at $50^{\circ} \mathrm{C}$. After incubation, the RT reaction was terminated by adding $0.5 \mathrm{M} \mathrm{NaOH} / 50 \mathrm{mM}$ EDTA, and neutralized in Tris buffer. Probes generated for the two different exposure conditions were mixed and concentrated using YM30 columns. Each cDNA probe mix was diluted in water and hybridization buffer to a total volume of $60 \mu \mathrm{L}$ according to the manufactures' protocol. cDNA probe hybridization was performed overnight at $60^{\circ} \mathrm{C}$ using a Advalytix SlideBooster SB800 (Advalytix AG, Brunnthal, Germany). After cDNA probe hybridization, slides were washed in $2 \times \mathrm{SSC} / 0.1 \% \mathrm{SDS}$ at $55^{\circ} \mathrm{C}$ for $10 \mathrm{~min}$, then washed $(3 \times 5 \mathrm{~min})$ in $1 \mathrm{x}$ SSC at RT and finally washed $(2 \times 5 \mathrm{~min})$ in $0.1 \mathrm{x}$ SSC at RT. Thereafter, hybridization of 3DNA Array 350 Capture Reagent was performed for $2.5 \mathrm{~h}$ before slide wash as described above and drying by compressed air. Finally, slides were dipped in a stabilization and drying solution (Agilent Technologies, CA, USA) for $30 \mathrm{~s}$ and scanned using an Agilent G2505B micro array scanner.

\subsection{Array experimental design and statistical analysis}

For both treatments in the experiment ( $\mathrm{T}$ and 11-KT) microarrays were used to study gene expression levels at two different time points
( 5 and 10 days) and three different concentrations ( 0 (solvent control), 10 and $100 \mu \mathrm{M})$, six conditions in total. For each condition three biological replicates were available. To compare the experimental conditions, 36 arrays were used for each treatment (11-KT and T) and co-hybridizations were performed according to a loop design, in which all biological replicates appeared in more than one array causing the arrays not to be statistically independent. The images from the scanned arrays were processed using the GenePix Pro 5.1 software. The data were then filtered to remove spots that had been flagged 'Absent', 'Not Found' or 'Bad'. Spots that had more than $20 \%$ saturated pixels, or had a mean foreground intensity less than 1.5 times the local median background intensity were also removed. No background subtraction was performed. The data from each array were log-transformed and normalized using the global loess method (Yang et al., 2001). The arrays were then scaled to having the same median absolute deviation. The reason for using a global instead of printtip loess approach was the sparse information available for each subarray. For making statistical inference on differentially regulated genes the limma package (Smyth, 2004) was used. The limma approach is based on fitting a linear model to the expression data for each probe on a microarray. To adjust for the fact that the same biological replicate was used on more than one array a model was fitted with a coefficient for each replicate. From the model, contrasts could then be extracted between replicates from different experimental conditions. For each pair of experimental conditions hypothesis tests were performed to test if the expression level of the genes had changed. From the resulting $p$-values, $q$-values (Storey, 2002) were calculated. The $q$-value for a gene is the expected proportion of false positives one will get when calling that gene significant. For a gene to be considered significantly differentially expressed between two conditions its $q$-value was required to be lower than 0.05 , in effect controlling the false discovery rate (FDR) (Benjamini and Hochberg, 1995) for each comparison at a 0.05 level.

\subsection{Database submission}

The array data were prepared according to the "minimum information about microarray experiment" (MIAME) recommendations, and deposited in the ArrayExpress database (http://www.ebi.ac. uk/arrayexpress/) with accession number.

\subsection{Primer optimization, cloning and sequencing}

PCR primers for amplification of 106-246 bp gene specific PCR products were designed from conserved regions of the studied genes. The primer sequences, their amplicon size and the optimal annealing temperatures are shown in Table 1. Prior to PCR reactions, all primer pairs were used in titration reactions in order to determine optimal primer pair concentrations and their optimal annealing temperatures. All chosen primer pair concentrations used at the selected annealing temperatures gave a single band for the expected amplicon size in all reactions.

\subsection{Quantitative (real-time) PCR}

The expression of individual gene targets was analyzed using the Mx3000P REAL-TIME PCR SYSTEM (Stratagene, La Jolla, CA, USA). Every $25-\mu \mathrm{L}$ DNA amplification reaction contained $12.5 \mu \mathrm{L}$ of iTAQ $^{\text {TMYBR }}{ }^{\circledR}$ Green Supermix with ROX (Bio-Rad), $5 \mu \mathrm{L}$ of diluted cDNA and $200 \mathrm{nM}$ of each forward and reverse primers. The 3-step real-time PCR program included an enzyme activation step at $95{ }^{\circ} \mathrm{C}$ (5 min) and 40 cycles of $95^{\circ} \mathrm{C}(30 \mathrm{~s}), 52-60{ }^{\circ} \mathrm{C}$ for $30 \mathrm{~s}$, depending on the primers used (see Table 1 ) and $72{ }^{\circ} \mathrm{C}(30 \mathrm{~s}$ ). Controls lacking cDNA template were included to determine the specificity of target cDNA amplification. Cycle threshold $(\mathrm{Ct})$ values obtained were converted into mRNA copy number using standard plots of Ct versus log copy number. Standard plots for each target sequence were generated using 
Table 1

Primer pair sequences, amplicon size and annealing temperature conditions for gene transcripts analyzed by real-time PCR

\begin{tabular}{|c|c|c|c|c|c|}
\hline \multirow[t]{2}{*}{ Target gene } & \multicolumn{2}{|l|}{ Primer sequence $^{a}$} & \multirow[t]{2}{*}{ Amplicon size (bp) } & \multirow[t]{2}{*}{ Annealing temp. $\left({ }^{\circ} \mathrm{C}\right)$} & \multirow[t]{2}{*}{ Genbank accession no. } \\
\hline & Forward & Reverse & & & \\
\hline ZPA & CACATCAGCTCACCCTCAGA & GACGCCCTACTAGTCCCACA & 106 & 60 & ES880740 \\
\hline Cyclin-B & CGGGAGATGGAGATGACTGT & TCTCGTAGTCCACCATGCAG & 150 & 58 & CO542315 \\
\hline HSP90 $\beta$ & CAGGAACCAGGTAGGCAGAG & CCAAAACCGGACCTAATCAA & 144 & 55 & ES880664 \\
\hline StAR & CAACGTCAAGCAGGTCAAGA & GCATCGGGCTTCAACACTAT & 246 & 52 & AY291434 \\
\hline P450scc & AACAACTACTTCCGCAGCCT & CGGTAGAACAATGAGCTGGA & 170 & 55 & AY706102 \\
\hline
\end{tabular}

a Sequences are given in the $5^{\prime}-3^{\prime}$ orientation.

known amounts of plasmid containing the amplicon of interest. The criterion for using the standard curve is based on equal amplification efficiency with unknown samples, and this was checked prior to extrapolating unknown samples to the standard curve. Data obtained from triplicate runs for individual target cDNA amplification were averaged and expressed as ng/ $\mathrm{g}$ of initial total RNA used for reverse transcriptase (cDNA) reaction and thereafter transformed as percentage of control. This absolute quantification method is a well-validated procedure in our laboratory, as we do not use the so-called housekeeping genes because of their parallel modulation pattern with experimental samples both in our laboratory (Arukwe, 2006) and elsewhere (Steele et al., 2002).

\subsection{In situ hybridization}

In situ hybridization procedures were performed according to standard protocols (Morel and Cavalier, 2001). Briefly, the orientation of insert relative to the T7 or SP6 RNA promoter binding site was determined, using the promoter at the $3^{\prime}$ end of the insert to get an antisense probe. A PCR analysis with primers flanking/including promotor binding sites generated $1 \mu \mathrm{g}$ of DNA. In vitro transcription with SP6 or T7 RNA polymerase was performed with a DIG RNA labelling kit (Roche, Mannheim, Germany) according to the manufacturer's protocol. The riboprobe was purified after DNasel digestion with lithium chloride precipitation. Thereafter, the DIG-labelled riboprobe was dissolve in DEPC-water to get a concentration of about $0.1 \mu \mathrm{g} / \mu \mathrm{L}$. One microliter of riboprobe was then run in an agarose gel to check riboprobe generation and then stored at $-80^{\circ} \mathrm{C}$ until used. When running slides, controls were made both by omitting the antisense probe and using a sense probe, getting no signal for both conditions.

\subsection{Previtellogenic oocyte histological and stereological analyses}

Cultured cod previtellogenic gonadal tissues were fixed in 4\% paraformaldehyde in $0.1 \mathrm{M}$ sodium phosphate buffer ( $\mathrm{pH} 7.4$ ) for $24 \mathrm{~h}$. After fixation, the tissues were washed twice in $70 \%$ ethanol, dehydrated in a graded series of ethanol baths using an automatic tissue processor (Leica Microsystems, Nussloch, Germany), cleared in Tissue-Clear®, embedded in paraffin blocks, sectioned at $4 \mu \mathrm{m}$ and stained with Mayer's haematoxylin and eosin. Tissues were examined using a workstation made with a microscope (Olympus BX-50, Tokyo, Japan) equipped with a complete rage of infinity-corrected objectives and a matching condenser, a microcator (Heidenhain MT-12, Traumrent, Germany) to control the movements in $z$-axis (accuracy $0.5 \mu \mathrm{m}$ ), a motorized stage (Prior, Fulbourm, UK) for stepwise displacement in $x-y$ axis (accuracy $1 \mu \mathrm{m}$ ), and a CCD video camera (Sony, Tokyo, Japan) connected to a PC monitor (Sony). The whole system was controlled by the software Olympus CAST-Grid (version 1.5).

A classification system for previtellogenic cod oocytes was developed based on previous studies of oocyte development in tilapia (Rocha and Rocha, 2006) and cod (Kjesbu and Kryvi, 1989) and is presented in Table 2. For the stereological evaluation, tissue slides were analysed under the $20 \times$ objective lens. Volume fractions of the different stages of oocytes were calculated by stereological point- counting (Freere and Weibel, 1967). According to size and frequency of each oocyte stage, a particular two-lattice point grid was used; 1:4 and 1:6. The interpoint distances (in $\mu \mathrm{m}$ ) for the sets were approximately: 77 (horizontal), 53 (vertical), for the 1:4 grid; and 51 (horizontal), 35 (vertical), for the $1: 6$ grid. The $1: 4$ point set of points was used to count hits over the reference space (ovary) versus oocytes of primary growth, whereas the 1:6 set of points was used to count hits over the reference space (ovary) versus all other oocyte classes and spermatozoa (when present). The first field of vision was selected randomly and thereafter, fields were systematically sampled by stepwise movements of the stage in $x$ - and $y$-directions ( step $_{x, y}=600 \mu \mathrm{m}$ ). The grid points directly overlying structures were recorded. This procedure was repeated on a number of systematically chosen fields within tissue pieces exposed to different concentrations of $11-\mathrm{KT}$ and T $(n=3)$, in order to obtain a total of at least 300 recorded grid points per tissue piece, which is generally accepted in order to establish a variance of about 5\% (Weibel, 1979). The same individual (T.M.K.) performed all the measurements and countings. The proportional volume fraction $\left(V_{\mathrm{V}}\right)$ (calculated as percentage) occupied by each stage of oocyte development was then estimated, according to the general formula: $V_{\mathrm{V}}$ (structure, reference $)=V_{\mathrm{V}}(s, r)=100 \times[P(s)] /[R \times P(r)]$, in which $V_{\mathrm{V}}$

Table 2

Classification of developmental stages of Atlantic cod previtellogenic oocytes

\begin{tabular}{|c|c|c|}
\hline $\begin{array}{l}\text { Previtellogenic oocyte } \\
\text { developmental stage }\end{array}$ & Main cellular characteristics & Histological images \\
\hline Proliferating oogonia & $\begin{array}{l}\text { Small nests of mitotic cells dispersed } \\
\text { within the connective tissue. } \\
\text { Oogonia are small and circular, with a } \\
\text { clear cytoplasm. Bar }=10 \mu \mathrm{m} \text {. }\end{array}$ & \\
\hline Initial primary growth & $\begin{array}{l}\text { Primary oocytes had one large, } \\
\text { usually peripheral nucleus. The } \\
\text { oocyte is still attached to the } \\
\text { connective tissue. The cytoplasm is } \\
\text { strongly basophilic due to the high } \\
\text { RNA concentration. Bar }=10 \mu \mathrm{m} \text {. }\end{array}$ & \\
\hline $\begin{array}{l}\text { Primary } \\
\text { previtellogenic growth }\end{array}$ & $\begin{array}{l}\text { Primary oocytes showed one large, } \\
\text { centrally located nucleus with } \\
\text { several basophilic nuclei at the } \\
\text { periphery. The cytoplasm stains also } \\
\text { basophilic. Follicular cells are scarce } \\
\text { and undifferentiated. Bar }=15 \mu \mathrm{m} \text {. }\end{array}$ & \\
\hline $\begin{array}{l}\text { Advanced } \\
\text { previtellogenic growth }\end{array}$ & $\begin{array}{l}\text { The oocyte becomes a larger cell. The } \\
\text { cytoplasm has more vesicles and } \\
\text { becomes less basophilic due to a } \\
\text { decreased RNA concentration. The } \\
\text { follicular cells are appearing and } \\
\text { begin differentiating. Bar }=30 \mu \mathrm{m} \text {. }\end{array}$ & \\
\hline
\end{tabular}


Table 3

Genes whose expression patterns were either up- or down-regulated by exposure of previtellogenic cod oocyte cultures to 11-ketotestosterone (11-KT) and testosterone (T), using targeted cod cDNA array (CodArray) analysis

$10 \mu \mathrm{M} 11-\mathrm{KT}$ exposure at day 10 compared with $10 \mu \mathrm{M}$ 11-KT Log. ratio exposure at day 5 .

\section{Putative gene identity}

tRNA pseudouridine synthase $A$

H/ACA ribonucleoprotein complex subunit 2

NifU-like $\mathrm{N}$-terminal domain containing protein

Cytochrome c oxidase polypeptide VIc precursor

Heat shock protein HSP 90-beta

$100 \mu \mathrm{M} 11-\mathrm{KT}$ exposure at day 10 compared with $100 \mu \mathrm{M}$

Log. Ratio

11-KT exposure at day 5.

Putative gene identity

H/ACA ribonucleoprotein complex subunit 2

tRNA pseudouridine synthase $A$

0.78

PHD finger-like domain protein $5 A$

0.72

Cytochrome c oxidase polypeptide VIc precursor

0.57

DKN2A interacting protein

Zona pellucida-like protein $\mathrm{X} 1$

40 S ribosomal protein $S 27$

Cyclin-B

Sentrin-related protein

Apoptosis-inducing TAF9-like domain 1

Heat shock protein HSP 90-beta

$40 \mathrm{~S}$ ribosomal protein $\mathrm{S} 11$

Zona pellucida protein $\mathrm{X} 2$

Egg envelope glycoprotein

ZPA domain containing protein

0.62

0.60

0.43

0.40

0.37

$-0.35$

$-0.43$

$-0.53$

$-0.78$

$-0.80$

$-0.74$

$100 \mu \mathrm{M}$ 11-KT exposure at day 10 compared with control at day 10 .

Putative gene identity

H/ACA ribonucleoprotein complex subunit 2

Zona pellucida-like protein $\mathrm{X}$

0.68

Cyclin-B

0.59

PHD finger-like domain protein $5 \mathrm{~A}$

$10 \mu \mathrm{M}$ T exposure at day 5 compared with control at day 5 .

Putative gene identity

ZPA domain containing protein

Zona pellucida protein $\mathrm{X} 2$

PHD finger-like domain protein $5 \mathrm{~A}$

0.35

0.32

$-0.33$

$100 \mu \mathrm{M}$ T exposure at day 5 compared with control at day 5 .

Log. Ratio

Putative gene identity

FK506-binding protein 3

Cytochrome c oxidase polypeptide VIc precursor

Zona pellucida protein $\mathrm{X} 2$

Heat shock protein HSP 90-beta

PHD finger-like domain protein $5 \mathrm{~A}$

$100 \mu \mathrm{M}$ T exposure at day 5 compared with $10 \mu \mathrm{M}$ T exposure

at day 5 .

Putative gene identity

Heat shock protein HSP 90-beta

ZPA domain containing protein

Heat shock protein HSP 70

Zona pellucida protein $\mathrm{X} 2$

$-0.48$

$-0.52$

$-0.54$

$10 \mu \mathrm{M}$ T exposure at day 10 compared with $10 \mu \mathrm{M}$ T exposure

Log. ratio at day 5 .

Putative gene identity

H/ACA ribonucleoprotein complex subunit 2

Zona pellucida protein $\mathrm{X} 2$

$-0.32$

$-0.38$

$10 \mu \mathrm{M}$ T exposure at day 10 compared with control at day 10 .

Log. ratio
Table 3 (continued)

$100 \mu \mathrm{M}$ T exposure at day 10 compared with $100 \mu \mathrm{M}$ T exposure at day $5 . \quad$ Log. Ratio

Putative gene identity

Heat shock protein HSP 70

0.77

ZPA domain containing protein

0.65

0.54

Heat shock protein HSP 90-beta

Zinc finger $\mathrm{CCHC}$ domain containing protein 10

Ribonucleoside-diphosphate reductase M2

Cytochrome c oxidase polypeptide VIc precursor

THAP domain containing protein 4

Sentrin-related protein

Each data point is derived from three biological replicates $(n=3)$ and $\log 2$-transformed. Some data points are mean values of several redundant clones (see supporting information). All values represented are significantly different $(q<0.05)$.

$(s, r)$ is the percentage of the total volume of a reference space occupied by one "particle" within that space, $P(s)$ is the number of points over the "particles" of interest, $R$ is the ratio of fine to coarse points ( 4 or 6 ), and $P(r)$ is the total number of points falling over the reference space.

\subsection{Steroid hormone analysis}

11-ketotestosterone concentrations were measured in gonad tissues cultured for $24 \mathrm{~h}$ using enzyme immunoassay (EIA) kits from Cayman Chemical Company (Ann Arbor, MI, USA). Tissues were thawed on ice, homogenized in 1:4 volume of $0.1 \mathrm{M}$ Na-phosphate buffer and centrifuged at $14,000 \times \mathrm{g}$ for $15 \mathrm{~min}$. The supernatants were purified by extraction using organic solvent to prevent the interference of lipids and proteins in the analysis. Briefly, the supernatant was mixed with $4 \mathrm{ml}$ diethyl ether using a vortex mixer. After phase separation, the aqueous portion was frozen in an ethanol/dry ice bath. The lipophilic phase was decanted into a clean tube, and the ether phase was evaporated by heating to $30{ }^{\circ} \mathrm{C}$. The dry extract was reconstituted in $300 \mu \mathrm{L}$ EIA buffer by vortexing. Enzyme immunoassay was run according to the manufacturer's protocol. Data were quantified against a standard curve that was linearized using a logit transformation of B/B0 (bound sample/maximum bound).

\subsection{Statistical analysis}

Statistics was performed with GraphPad Prism, version 2.1 (GraphPad Software Inc). Significant differences between control and exposure groups were performed using one-way ANOVA after testing for normality and variance homogeneity. Statistical differences between exposure groups were analyzed using the Tukey's Multiple Comparison Test. The level of significance was set at $p \leq 0.05$.

\section{Results}

\subsection{SSH and array gene expression pattern}

150 expressed sequences from the subtracted cDNA library were grouped into 54 UniGene entries (putative genes), and there were 23 contigs of two or greater (groups of clones probably representing overlapping regions) and 31 singletons. Table 3 shows a summary of genes whose expression patterns were significantly modulated after exposure to different concentrations of 11-KT and $\mathrm{T}$ in the array analysis. For complete lists of all genes, including unknown and redundant sequences, size of queries, Blast e-values and accession numbers, see the Supplemental data. The array analyses showed that exposure of previtellogenic oocytes to androgens produced differential gene expression patterns, showing 0.5 -3.5-fold significant alterations of transcript levels from genes mainly of oocyte origin, as well as a number of transcripts whose function in fish are yet to be identified (see Supplemental data). Treatment with androgens produced modulations in mRNA levels of some zona radiata associated genes. Additionally, 11- 
(A)

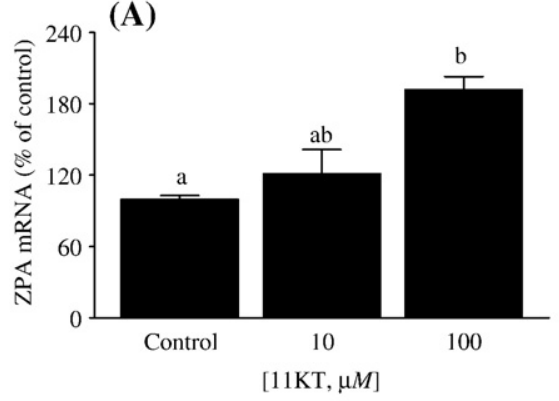

(C)

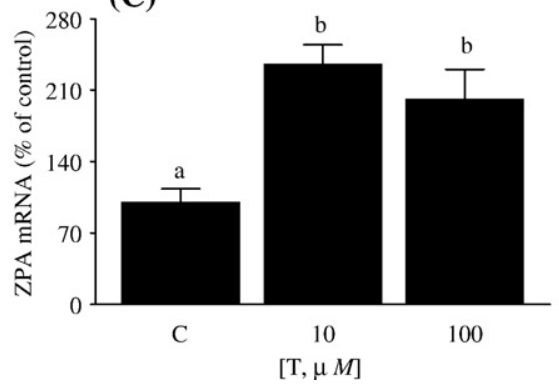

(B)

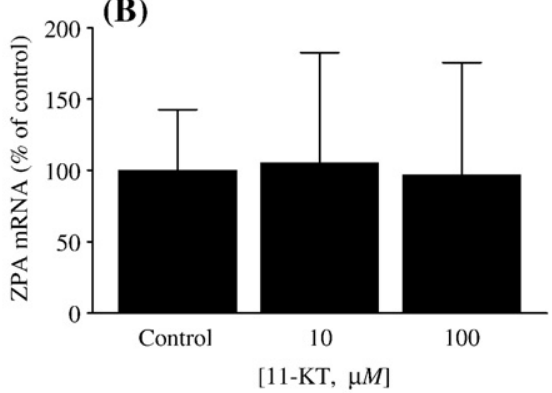

(D)

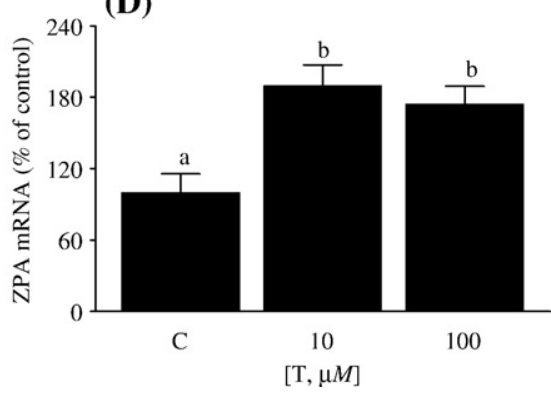

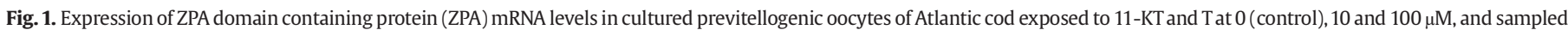

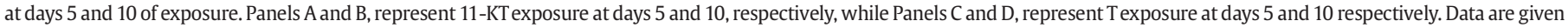
as mean expressed as percentage $(\%)$ of control $(n=3) \pm$ standard error of the mean (SEM). Different letters denote exposure groups that are significantly different $(p<0.05)$.

KT treatment was associated with an induced transcription of cyclin-B. The array data indicated that previtellogenic oocytes exposed to the highest 11-KT concentration $(100 \mu \mathrm{M})$ experienced the strongest modulations of gene transcripts on the CodArray. Significant alterations of transcript levels for individual genes were usually observed in samples exposed both to the low (10) and high $(100 \mu \mathrm{M})$ androgen concentrations. Furthermore, the array data demonstrate that gene expression patterns varied within a given exposure and/or time of exposure.

\subsection{Real-time PCR ( $q P C R)$ analyses of selected transcripts}

On the basis of previous studies and the results obtained from the array analysis, we selected five genes for quantitative analysis using real-time PCR with gene specific primer pairs; ZPA domain containing protein (ZPA), cyclin-B, heat shock protein 90 $\beta$ (Hsp90ß), StAR and $\mathrm{P} 450$ scc. The primary criterion for selecting these genes for real-time PCR validation was because they belong to our targeted study objectives, namely growth and development of previtellogenic oocytes and because they showed modulated expression patterns on the array analysis or in previous studies in our laboratory.

At day 5 of exposure, the expression of ZPA after 11-KT and T exposure showed an apparent concentration-dependent increase in mRNA expression (Fig. 1A and C, respectively). At day 10 of exposure, a different pattern of expression was observed for tissues exposed to 11KT (Fig. 1B), showing no differences, either within the exposure groups or compared with the solvent control. On the contrary, exposure to $\mathrm{T}$

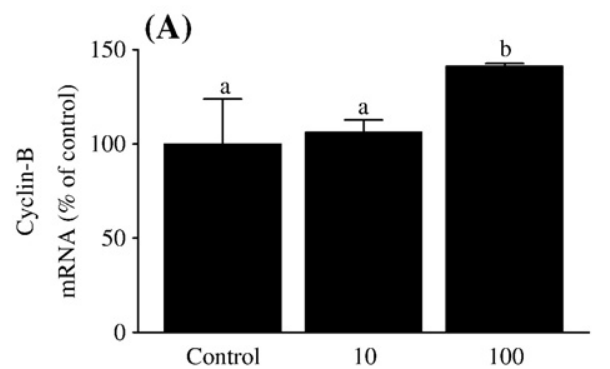

$[11-\mathrm{KT}, \mu M]$

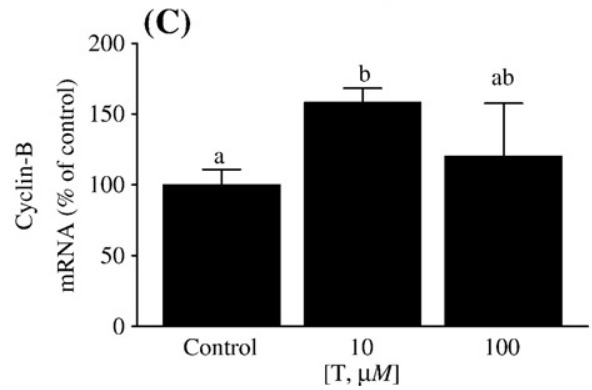

(B)

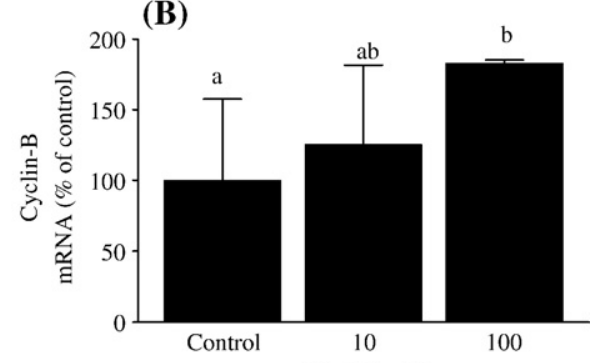

$[11-\mathrm{KT}, \mu M]$

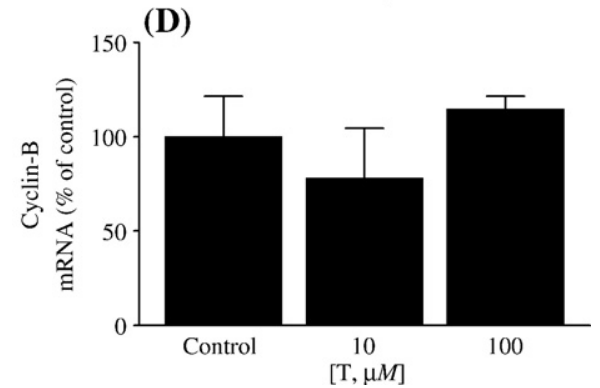

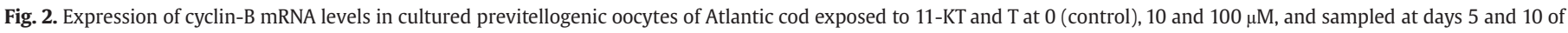

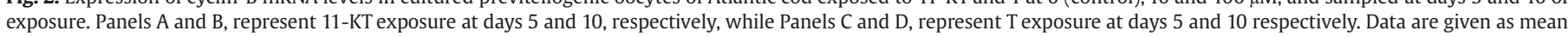
expressed as percentage (\%) of control $(n=3) \pm$ standard error of the mean (SEM). Different letters denote exposure groups that are significantly different ( $p<0.05$ ). 


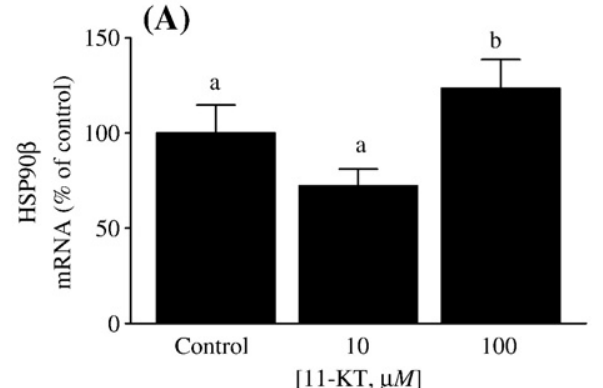

(C)

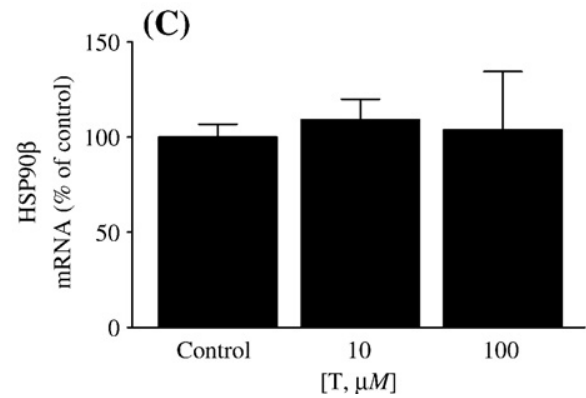

(B)

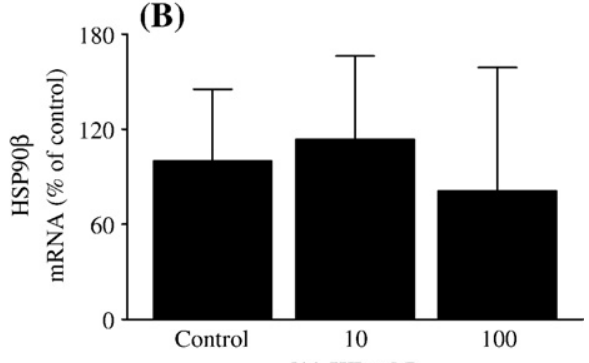

$[11-\mathrm{KT}, \mu M]$

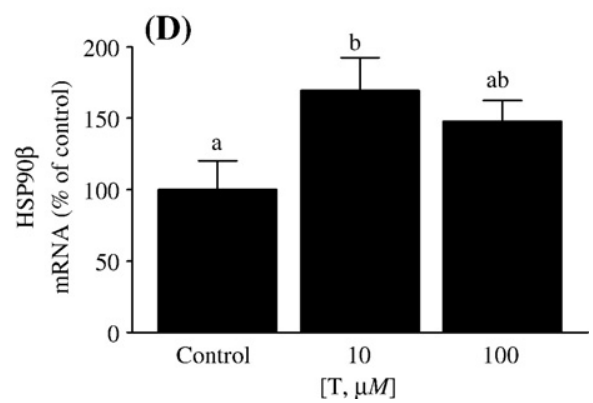

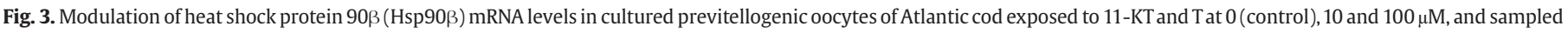

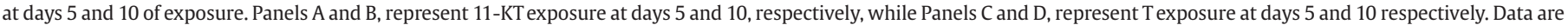
given as mean expressed as percentage $(\%)$ of control $(n=3) \pm$ standard error of the mean (SEM). Different letters denote exposure groups that are significantly different $(p<0.05)$.

concentrations produced a respective 2-fold increase in ZPA expression at day 10 of exposure, compared to the solvent control (Fig. 1D).

The expression of cyclin-B in cod previtellogenic oocytes was modulated after exposure to different concentrations of 11-KT in a concentration-specific manner at days 5 and 10 of exposure (Fig. 2A and $B$, respectively). A general pattern of increase in cyclin-B mRNA expression was observed, reaching a 1.5- and 2-fold increase for groups exposed to the highest $11-\mathrm{KT}$ concentration $(100 \mu \mathrm{M})$ compared to the control at days 5 and 10 , respectively. At day 5 of exposure, the expression pattern of cyclin-B in tissues exposed to T showed a 1.5 -fold increase in the group exposed to $10 \mu \mathrm{M}$. No differences in expression of cyclin-B between groups exposed to $\mathrm{T}$ were observed at day 10 of exposure (Fig. 2D).
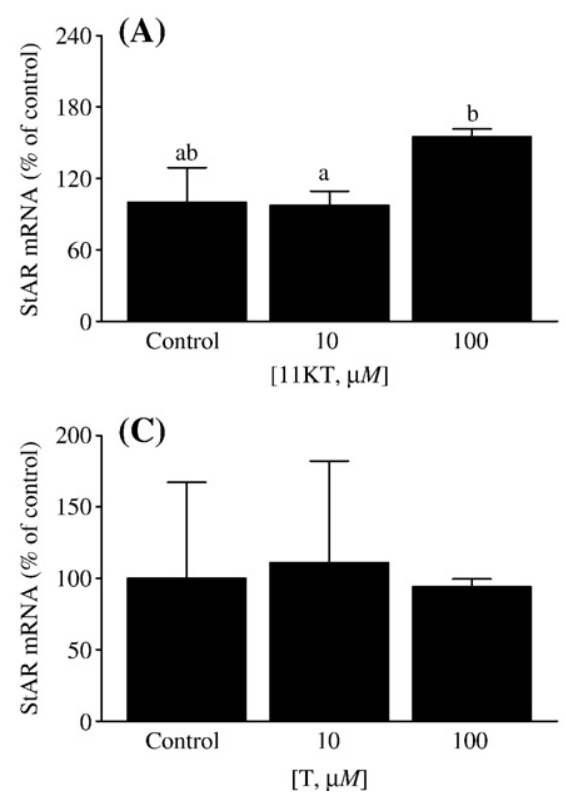

The expression of Hsp90 $\beta$ in cod previtellogenic oocytes was modulated after exposure to different concentrations of 11-KT and $\mathrm{T}$ at days 5 and 10 of exposure (Fig. 3). At day 5, $100 \mu \mathrm{M}$ 11-KT produced a minor, but significant increase in Hsp90ß expression (Fig. 3A). On the contrary, no significant differences between 11-KT exposure groups and solvent control were observed at day 10 of exposure (Fig. 3B). Tissues incubated with $\mathrm{T}$ showed no significant differences at day 5 of exposure, compared to the solvent control (Fig. 3C) and an apparent T concentration-dependent effect was observed at day 10 of exposure (Fig. 3D).

Quantification of StAR mRNA showed expression profiles for tissues exposed to 11-KT and T that were time- and concentration-specific responses. At day 5 of exposure, a 0.5 -fold significant increase in StAR mRNA was observed for samples exposed to the highest 11-KT
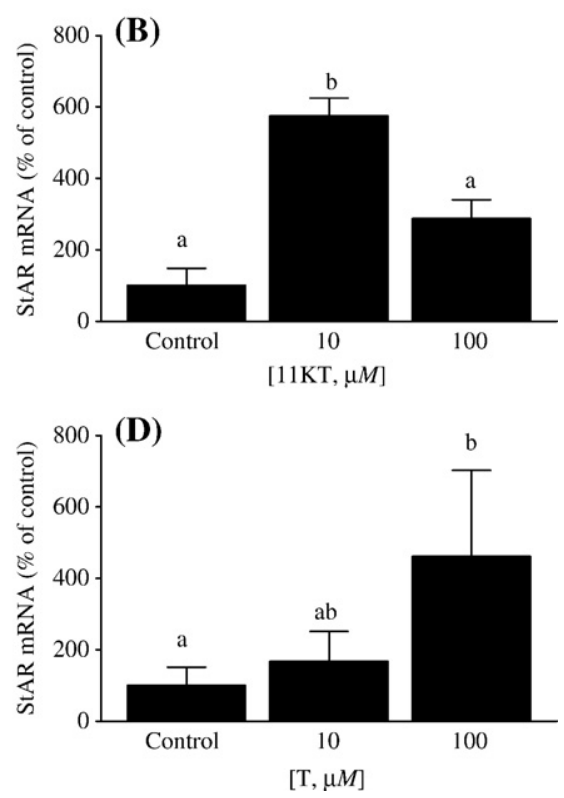

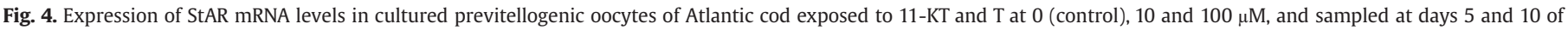

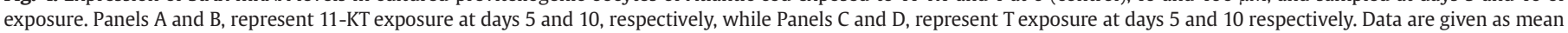
expressed as percentage (\%) of control $(n=3) \pm$ standard error of the mean (SEM). Different letters denote exposure groups that are significantly different $(p<0.05)$. 


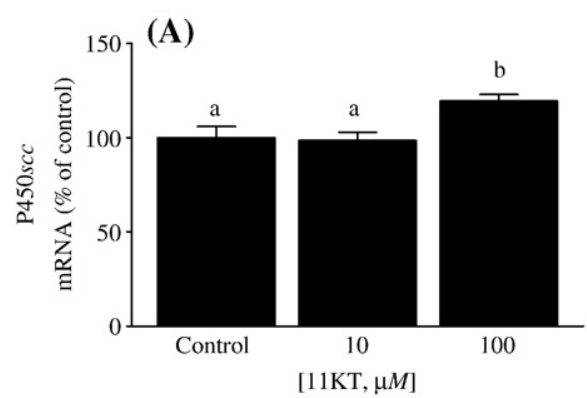

(C)

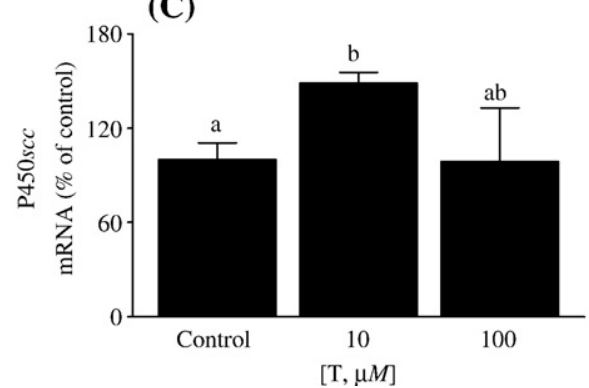

(B)

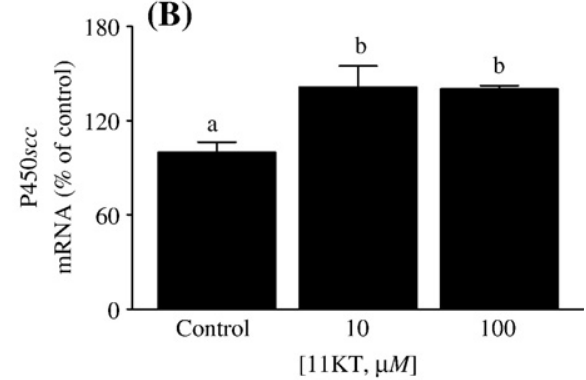

(D)

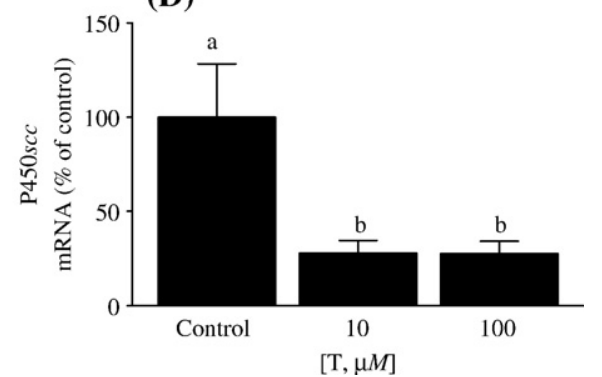

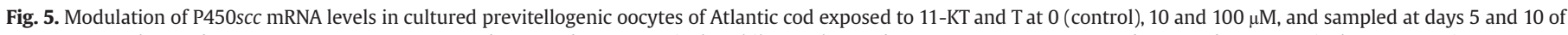

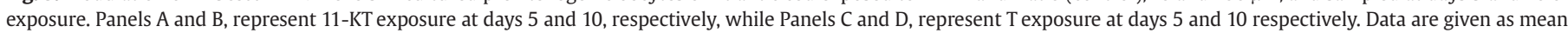
expressed as percentage (\%) of control $(n=3) \pm$ standard error of the mean (SEM). Different letters denote exposure groups that are significantly different ( $p<0.05$ ).

concentration (100 $\mu \mathrm{M}$, Fig. 4A) whereas 11-KT displayed a concentration-specific modulation of StAR mRNA levels at 10 days cultivation (Fig. 4B) with $10 \mu \mathrm{M} 11-\mathrm{KT}$ producing the only significant increase compared the solvent control. No differences in StAR expression were observed for tissues exposed to Tat day 5 (Fig. 4C). At day 10 of exposure, treatment with $\mathrm{T}$ produced a concentration-specific modulation of StAR levels, displaying a 4-fold increase for samples exposed to $100 \mu \mathrm{M}$, compared to control (Fig. 4D).

For P450scc, we observed a 0.2-fold significant increase of P450scc expression in tissues exposed to $100 \mu \mathrm{M}$ 11-KT (Fig. 5A). A similar expression pattern was observed at day 10 of exposure, showing significant increase of P450scc mRNA levels for samples exposed to 10 and $100 \mu \mathrm{M} 11-\mathrm{KT}$ (Fig. 5B). At day 5 of exposure, an apparent concentration-dependent effect was observed, showing significant increase for samples exposed to $10 \mu \mathrm{M} \mathrm{T}$, compared to control (Fig. 5C). Interestingly, tissues exposed to T produced a consistent decrease of P450scc expression at day 10 of exposure, showing 3-fold decreases for samples exposed to both $\mathrm{T}$ concentrations, compared to the control (Fig. 5D).

\subsection{Histology and stereological analysis of cod oocyte growth and development}

All the gonadal tissues examined displayed normal histology. The volume densities (\%) of the different previtellogenic oocyte developmental stages in relation to total gonadal tissue volume in pieces exposed

Table 4

Volume densities (\%) of previtellogenic oocyte developmental stages in relation to total gonadal tissue volume $(n=3)$ in tissues exposed to 11-ketotestosterone (11-KT)

\begin{tabular}{|c|c|c|c|c|c|c|}
\hline \multirow{2}{*}{$\begin{array}{l}\text { 11-ketotestosterone } \\
(\mu \mathrm{M})\end{array}$} & \multicolumn{3}{|l|}{ Day 5} & \multicolumn{3}{|l|}{ Day 10} \\
\hline & \multirow[t]{2}{*}{ Control } & \multirow[t]{2}{*}{10} & \multirow[t]{2}{*}{100} & \multirow[t]{2}{*}{ Control } & \multirow[t]{2}{*}{10} & \multirow[t]{2}{*}{100} \\
\hline $\begin{array}{l}\text { Previtellogenic oocyte } \\
\text { developmental stage }\end{array}$ & & & & & & \\
\hline 1st growth & $42 \pm 6$ & $51 \pm 6$ & $38 \pm 13$ & $34 \pm 4$ & $33 \pm 4$ & $31 \pm 6$ \\
\hline Advanced growth & $1.2 \pm 1.3$ & $2.8 \pm 1.2$ & $1.8 \pm 0.9$ & $4.9 \pm 1.8$ & $12.8 \pm 5.3$ & $13.6 \pm 5.2$ \\
\hline 1st atresia & $5.0 \pm 1.3$ & $4.2 \pm 1.2$ & $3.2 \pm 1$ & $1.8 \pm 0.4$ & $1.2 \pm 0.9$ & $1.0 \pm 0.3$ \\
\hline 2nd atresia & - & $0.3 \pm 0.4$ & $0.6 \pm 0.8$ & $3.7 \pm 2.1$ & $5.3 \pm 3.5$ & $5.7 \pm 3$ \\
\hline Spermatozoa & - & $0.4 \pm 1$ & $1.3 \pm 1$ & - & $1.4 \pm 1.5$ & $1.5 \pm 1.7$ \\
\hline
\end{tabular}

Data are expressed as mean \pm standard deviation. to different concentrations of 11-KT and Tare presented in Tables 4 and 5, respectively. In addition, the volume fractions of oocytes of advanced previtellogenic growth are presented in Fig. 6. At day 5 of exposure, tissues exposed to 11-KT showed significantly higher volume fractions of oocytes in advanced growth phase as compared to the solvent control (Table 4 and Fig. 6A). A 2-fold increase in advanced oocyte volume densities was observed for tissues exposed to $10 \mu \mathrm{M} 11-\mathrm{KT}$, whereas a 1.5 -fold increase was observed for the group exposed to $100 \mu \mathrm{M} 11-\mathrm{KT}$ at day 5. Induced development was also observed, in a dose-dependent manner, in tissues exposed to Tat day 5, where a 2- and 3.5-fold increase in volume fractions of oocytes in advanced previtellogenic growth phase was observed for tissues exposed to 10 and $100 \mu \mathrm{M}$ T, respectively (Table 5 and Fig. 6C). Ovary areas with high density of spermatozoa were observed at day 5 of exposure for tissues exposed to both concentrations of $11-\mathrm{KT}(10$ and $100 \mu \mathrm{M})$ and the highest concentrations of $\mathrm{T}(100 \mu \mathrm{M})$. The volume densities of atretic oocytes in all exposure groups (both 11KT and T) were generally 3-5\%, showing no significant differences between control and androgen exposed tissues. Furthermore, the volume densities of oocytes in primary growth phase were by far the most abundant in all tissues, showing volume fractions between 28 and $50 \%$. No significant differences in primary oocyte volume densities were observed between control and androgen exposed tissues.

At day 10 of exposure, tissues exposed to $11-\mathrm{KT}(10$ and $100 \mu \mathrm{M})$ showed significantly higher volume fractions of oocytes in advanced previtellogenic growth phase compared to the solvent control (Table 4

Table 5

Volume densities (\%) of previtellogenic oocyte developmental stages in relation to total gonadal tissue volume $(n=3)$ in tissues exposed to testosterone $(T) \pm$ standard deviatio">

\begin{tabular}{|c|c|c|c|c|c|c|}
\hline \multirow{3}{*}{$\begin{array}{l}\text { Testosterone }(\mu \mathrm{M}) \\
\text { Previtellogenic oocyte } \\
\text { developmental stage }\end{array}$} & \multicolumn{3}{|l|}{ Day 5} & \multicolumn{3}{|l|}{ Day 10} \\
\hline & \multirow[t]{2}{*}{ Control } & \multirow[t]{2}{*}{10} & \multirow[t]{2}{*}{100} & \multirow[t]{2}{*}{ Control } & \multirow[t]{2}{*}{10} & \multirow[t]{2}{*}{100} \\
\hline & & & & & & \\
\hline 1st growth & $33 \pm 6$ & $31 \pm 6$ & $33 \pm 6$ & $46 \pm 2$ & $31 \pm 9$ & $37 \pm 10$ \\
\hline Advanced growth & $1.7 \pm 0.9$ & $3.5 \pm 1.8$ & $5.8 \pm 1.7$ & $6.3 \pm 1.5$ & $14.4 \pm 2.4$ & $11.4 \pm 2.0$ \\
\hline $1^{\text {st }}$ atresia & $3.6 \pm 0.8$ & $4.4 \pm 1.5$ & $3.3 \pm 0.9$ & $2.1 \pm 0.6$ & $1.8 \pm 0.6$ & $1.5 \pm 0.5$ \\
\hline 2nd atresia & - & $0.2 \pm 0.4$ & $1.0 \pm 0.6$ & $1.2 \pm 1$ & $2.4 \pm 2.6$ & $4.5 \pm 2.3$ \\
\hline Spermatozoa & - & - & $0.1 \pm 0.2$ & - & $0.5 \pm 0.6$ & $0.6 \pm 0.4$ \\
\hline
\end{tabular}

Data are expressed as mean \pm standard deviation. 
(A)

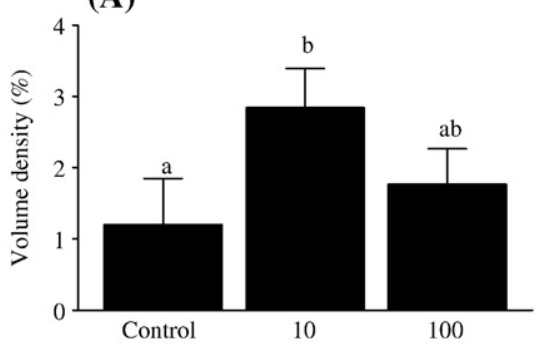

$[11-\mathrm{KT}, \mu M]$

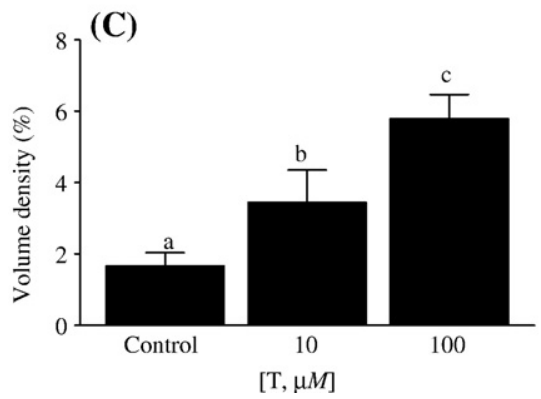

(B)

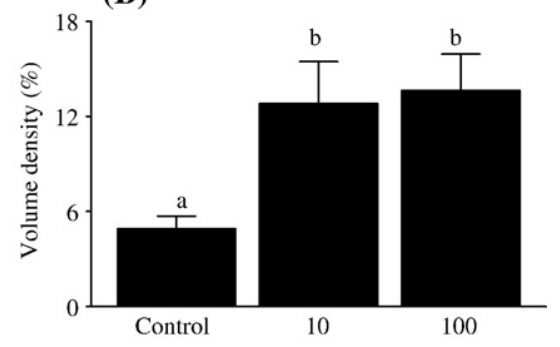

$[11-\mathrm{KT}, \mu M]$

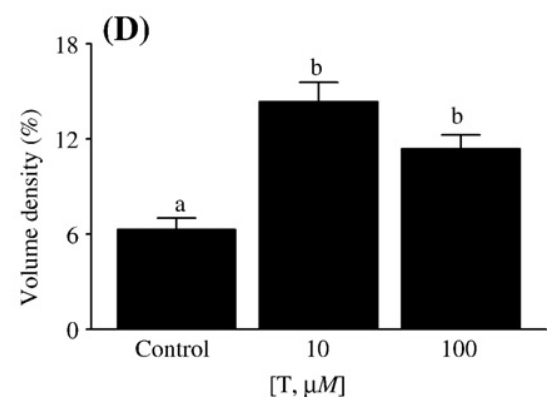

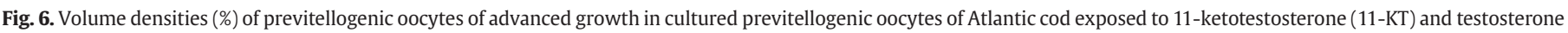

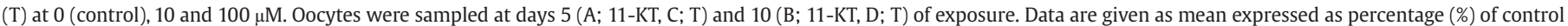
$(n=3) \pm$ standard error of the mean (SEM). Different letters denote exposure groups that are significantly different $(p<0.05)$.

and Fig. 6B), displaying a 2.6- and 2.8-fold increase in advanced oocyte volume densities for tissues exposed to 10 and $100 \mu \mathrm{M} 11-\mathrm{KT}$, respectively. The same pattern is also true for tissues exposed to $\mathrm{T}$ (Table 5 and Fig. 6D) showing a 2.3- and 1.8-fold increase in volume fractions of previtellogenic oocytes in advanced growth phase in tissues exposed to 10 and $100 \mu \mathrm{M} \mathrm{T}$, respectively. Ovary areas with high density of spermatozoa were observed at day 10 of exposure for tissues exposed to all concentrations of 11-KT and T, with minor, but significantly higher volume fractions observed in tissues exposed to 11-KT as compared to tissues exposed to T. The volume densities of atretic oocytes showed no significant differences between control and androgen exposed tissues. However, a general shift from primary to secondary atretic oocytes was observed at day 10 of exposure, compared to day 5 of exposure.

\subsection{In situ hybridization}

A summary of cellular localization of mRNA levels using in situ hybridization of ZPA and zona pellucida protein X2 (ZPX2) RNA probes on tissues exposed to 11-KT and T are presented in Table 6 and some representative micrographs are shown in Fig. 7. At 5 days of exposure, a clear positive probe signal was revealed only in the control sections for both treatments (11-KT and T). For both treatments (11-KT; Fig. 7B and T; Fig. 7C), ZPA was highly expressed at 10 days of exposure as compared to control (Fig. 7A). In all cases, the signal was stronger for samples exposed to $\mathrm{T}$ than samples exposed to 11-KT. In positive slides, the sections were generally characterized by smaller oocytes

Table 6

Summary of in situ RNA probe expression

\begin{tabular}{|c|c|c|c|c|c|c|c|c|}
\hline & \multicolumn{4}{|l|}{$11-\mathrm{KT}$} & \multicolumn{4}{|l|}{$\mathrm{T}$} \\
\hline & \multicolumn{2}{|c|}{ Control } & \multicolumn{2}{|c|}{$100 \mu \mathrm{M}$} & \multicolumn{2}{|c|}{ Control } & \multicolumn{2}{|c|}{$100 \mu \mathrm{M}$} \\
\hline & Day 5 & Day 10 & Day 5 & Day 10 & Day 5 & Day 10 & Day 5 & Day 10 \\
\hline$\overline{\mathrm{ZPA}}$ & + & + & $+1-$ & ++ & ++ & +++ & $+1-$ & ++++ \\
\hline ZPX2 & + & + & $+1-$ & ++ & ++ & +++ & $+1-$ & ++++ \\
\hline
\end{tabular}

++++ Very strong signal; +++ strong signal; ++ moderate signal; + weak signal; +/- weak or no signal. showing high levels of ZPA mRNA expression. Larger oocytes showed relatively lower expression levels. The expression of ZPX2 was similar to ZPA expression (Table 6, micrographs not shown).

\subsection{1-KT tissue levels}

In order to estimate androgen uptake by gonadal tissue cultures, we measured 11-KT concentrations in samples exposed to 0 (control), 10 and $100 \mu \mathrm{M} 11-\mathrm{KT}$ for $24 \mathrm{~h}(n=3)$. Solvent control tissues displayed a mean 11-KT concentration of $0.68 \mathrm{ng} / \mathrm{mg}$ tissue (Fig. 8). When compared with control samples, mean tissue 11-KT levels increased 10 and 30 -fold after exposure to 10 and $100 \mu \mathrm{M} 11-\mathrm{KT}$, respectively.

\section{Discussion}

Prior to overt morphological or developmental changes, the first interaction between a hormone and tissue occurs at the molecular and cellular levels of biological organization. Therefore, changes in gene expression as a result of hormonal exposure and the subsequent molecular processes that lead to developmental and physiological changes may be used as quantitative markers for cellular, physiological, developmental and reproductive effects in an organism. Herein, we show that gene expression patterns and the growth of cod previtellogenic gonadal tissues were modulated after exposure to androgens. Both 11-KT and T were capable of inducing previtellogenic oocyte growth and development, with 11-KT being the strongest modulator.

\subsection{Evaluation of SSH and CodArray data}

When genomic data for an organism is limited, such as the Atlantic cod, the SSH method can be a powerful tool for generating cDNA libraries containing DNA sequences of interest. The use of microarrays to screen cDNA clones generated by SSH also allows the identification of previously unknown genes-a finding that is not possible using conventional arrays of previously cloned genes (Yang et al., 1999). However, SSH usually generates a number of redundant clones in the subtracted sequences, and several genes suspected to be involved in the transcriptional regulation of oocyte growth and development 

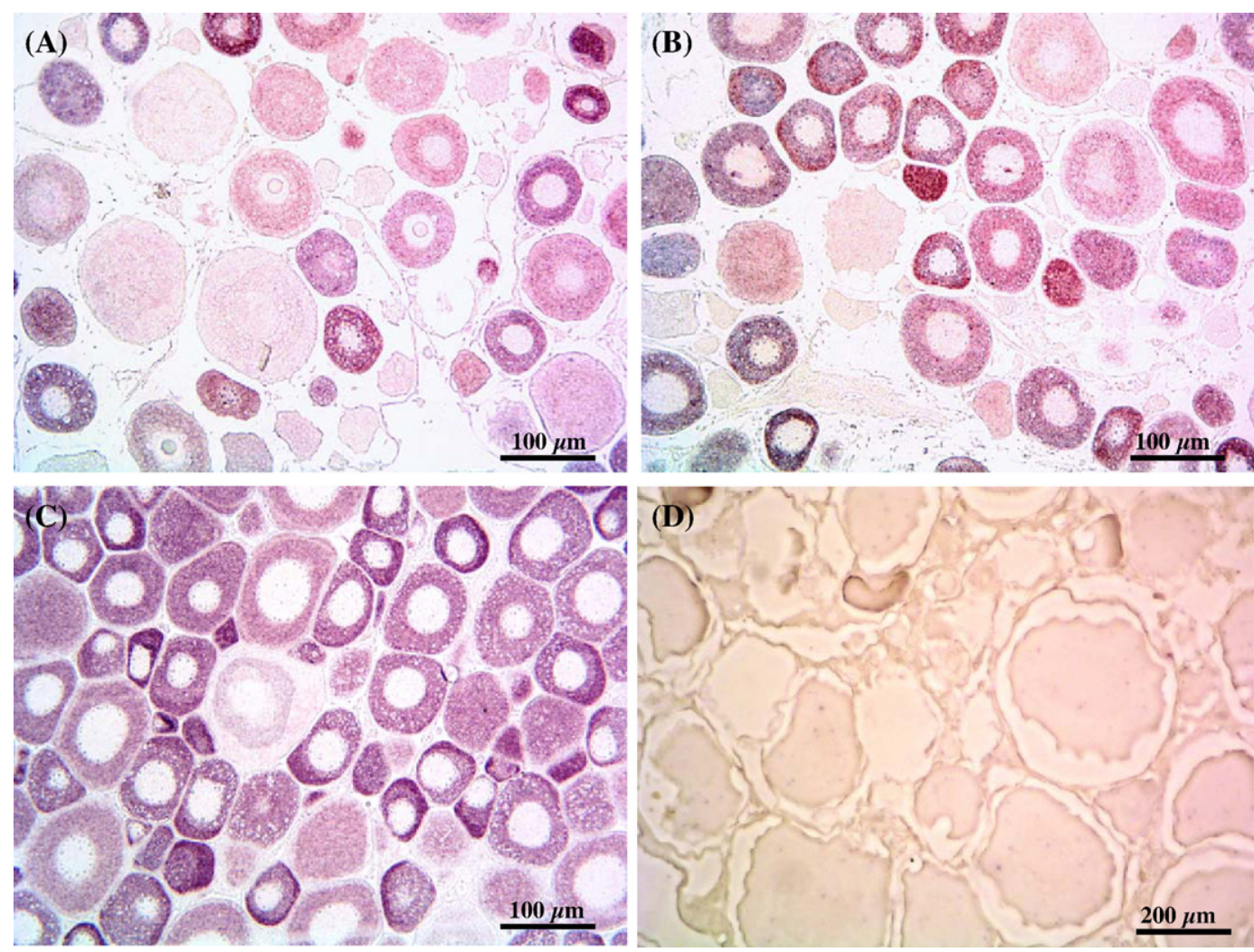

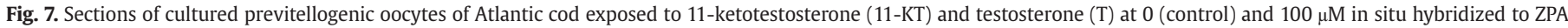

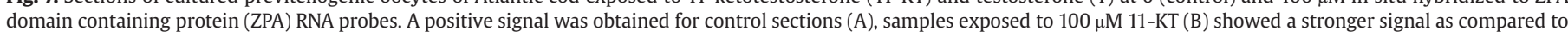

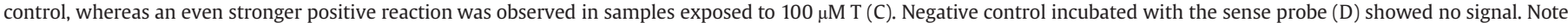
that Fig. 9 D has a 2× magnification compared with 9A, B and C, to visualize oocytes due to lack of signal.

were not represented after performing SSH in the present study. The reason for this is probably the low expression levels of these genes in cod ovarian tissue. In accordance, it is well known that SSH favours the enrichment of high abundance transcripts (Ji et al., 2002; Pan et al., 2006), which may result in over- or under-representation of certain transcripts in the subtracted library. Therefore, transcripts from some genes were amplified by PCR using specific primers from conserved regions of the respective genes based on sequence information in NCBI GenBank. The PCR products were cloned into E. coli plasmids, sequenced and subsequently added to the array.

Although the present study generated few sequences compared with other surveys, the number of gene profiles generated was already too high for suitable one by one analysis. Therefore, we performed an initial array screening with subsequent qPCR analyses of genes suspected to

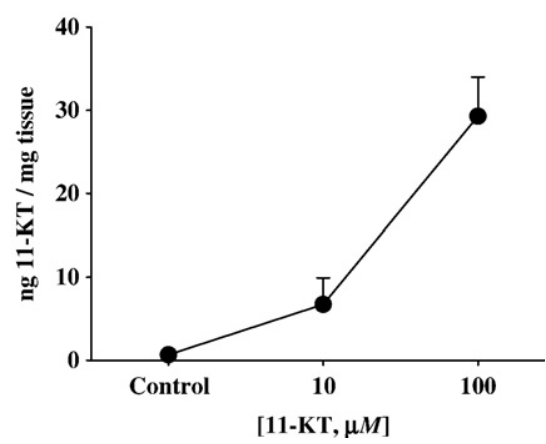

Fig. 8. 11-ketotestosterone (11-KT) levels in previtellogenic oocyte cultures of Atlantic cod incubated for $24 \mathrm{~h}$ with different 11-KT concentrations. 11-KT levels were determined using enzyme immunoassay method. Data are given as mean value and expressed as $\mathrm{ng} / \mathrm{mg}$ tissue (wet weight) of $n=3 \pm$ standard error of the mean (SEM). be involved in previtellogenic oocyte growth and development. After annotation of the sequenced clones, we found that the major part of the amplicons generated by SSH were of oocyte origin, whereas less abundant transcripts derived from ovarian follicle cells were likely not identified by the SSH method. In compliance, this has been observed earlier, and it has been proposed that construction of cDNA libraries enriched for extra-oocyte components such as the follicle wall will provide a better generation of transcripts from these ovarian components (Goetz et al., 2006; Luckenbach et al., 2008).

cDNA microarray techniques have some disadvantages compared to more tedious techniques such as qPCR. For example, they are limited in the detection of genes with low expression (Rondeau et al., 2005) and clones from less abundant mRNAs may fall within the 'noise' level of the hybridization signals (Yang et al., 1999). In addition, cDNA insert size may be a factor in reliably identifying differentially expressed genes, and short subtracted clones from the 5[prime]-end of cDNAs are less likely to give reliable hybridization signals than fulllength cDNAs (Yang et al., 1999). In the present study, array screening failed to identify some genes (e.g. StAR and P450scc) that were shown to be differentially expressed after androgen treatment by qPCR analysis. Additionally, validation of array values by qPCR demonstrated differences in expression profiles for the two methods in some instances. These differences might be due to the mentioned limitations of microarray techniques. To conclude, we believe the microarray approach should be considered a first screening, and qPCR probably produced more accurate molecular signatures, at least in the present study.

\subsection{Modulation of genes associated with the zona radiata}

The present study demonstrated high levels of ZP transcripts in the previtellogenic Atlantic cod ovary using qPCR and in situ hybridization 
analyses. Although some data show conflicting patterns, a general increased mRNA expression after androgen treatment was observed. In vertebrates, the egg envelope, which is of great importance for the sperm-egg interaction, consists of a family of related ZP proteins with a conserved ZP domain. Very recent studies have demonstrated that teleost species have at least three isoforms of ZP proteins, ZP1 (ZPB), ZP3 (ZPC) and ZPX (Modig et al., 2006; Modig et al., 2007). However, the $\mathrm{ZP}$ nomenclature is confusing, and this complicates comparison between mammalian and fish ZP genes, as well as between different teleost species (Arukwe and Goksøyr, 2003). Several other studies have demonstrated abundant levels of ZP transcripts in teleost oocytes during previtellogenic growth, displaying higher ZP mRNA levels in the more undeveloped stages of oocyte growth (Chang et al., 1997; Luckenbach et al., 2008; Zeng and Gong, 2002). Elsewhere, while E2 regulation of ZP synthesis is a well known phenomenon, androgens have been suggested to regulate ZPs in fish (Miura et al., 1998) and birds (Pan et al., 2001). Although not conclusive, the present study suggests that androgens can modulate the transcriptional profile of ZP genes in the previtellogenic cod ovary, possibly in correlation with development of the oocyte envelope.

\subsection{Effects on cyclin-B mRNA levels}

Final oocyte maturation is triggered by the maturation-promoting factor (MPF), and MPF comprises two components; the catalytic subunit cdc2 and the regulatory subunit cyclin-B (Kondo et al., 1997; Morgan, 1995). Cyclin-B transcripts have been demonstrated in immature oocytes of goldfish (Nagahama, 1997) and zebrafish (Kondo et al., 2001) but they are not translated until later, when the oocyte reach the maturation phase. Other studies have suggested that the accumulation of cyclin-B transcripts in oocytes is involved in the regulation of the early embryonic cell cycle (Aegerter et al., 2004), and that expression of cyclin-B in previtellogenic oocytes indicates somatic follicle cells undergoing mitotic divisions (von Schalburg et al., 2005). The present study demonstrates high levels of cyclin-B mRNA in the previtellogenic cod ovary, and we show that natural occurring androgens are able to increase cyclin-B transcription levels. Gene expression patterns of cyclin-B have been suggested as markers for early oocyte growth and developmental competence in teleost fish (Aegerter et al., 2004), but more studies assessing the regulation of cyclin-B transcription levels in specific oocyte developmental stages are needed in order to support this suggestion.

\subsection{Modulation of heat shock protein $90 \beta$ expression}

Heat shock proteins are a family of highly conserved intracellular proteins found in all organisms (Lindquist and Craig, 1988). Despite the fact that heat shock proteins are primitive and act to protect the cell against the cytotoxic consequences of protein degradation, a number of heat shock genes are expressed at high levels during normal cell growth (Morimoto et al., 1994). The expression of heat shock genes in teleost embryonic development have been investigated (Krone et al., 2003), as well as heat shock protein expression during oogenesis, where it has been shown that growing oocytes spontaneously express high levels of heat shock protein 70 and 90 (Neuer et al., 1999). Extensive molecular characterization and biochemical studies have demonstrated that vertebrate members of Hsp90 family play a post-translational regulatory role within the cell by interacting with several important cellular signalling molecules and transcription factors, such as steroid receptors, and modulating their activities (Krone et al., 1997). A recent large-scale genomic study describing expression profiles of zebrafish testis and ovary demonstrated that Hsp90 was the most abundant transcript in testis, whereas Hsp90 showed a much lower expression level in the ovary (Zeng and Gong, 2002). In contrast, this study demonstrated that Hsp90ß was among the most abundant transcripts in the previtellogenic cod ovary, and
11-KT and T produced increased Hsp90 $\beta$ mRNA levels, albeit showing time-dependent expression patterns. Thus, it seems likely that Hsp90 $\beta$ plays an important role in oocyte development, at least in Atlantic cod.

\subsection{Modulation of StAR and P450scc mRNA levels}

The rate-limiting step in steroidogenesis is the movement of cholesterol across the mitochondrial membrane by the StAR protein and the subsequent conversion to pregnenolone by the P450scc enzyme (Stocco, 2001). In mammals, StAR and P450scc are rapidly synthesized in response to acute tropic hormone stimulation and cAMP, and in general, agents that increase steroid biosynthesis also increase StAR mRNA expression (Stocco, 2001). However, current knowledge about StAR is mostly based on mammalian studies, whereas the relationship between StAR gene expression and steroid production in fish is not very well described (Hagen et al., 2006; Stocco et al., 2005). Interestingly, StAR expression data suggest that the molecular mechanisms of StAR synthesis and regulation in fish may differ from what has been previously observed in mammals (Goetz et al., 2004). The gene expressions of StAR presented in the present study show more than a 4-fold increase in StAR mRNA compared to control at day 10 of exposure for samples exposed to $10 \mu \mathrm{M} 11-\mathrm{KT}$ and $100 \mu \mathrm{M}$ T. Additionally, we observed differential expression patterns of StAR and P450scc. For example, samples exposed to T showed a general increase in StAR mRNA levels at day 10 of exposure, whereas a consistent decrease in P450scc mRNA expression was observed at the same time interval. These findings are in contrast with a previous study by Geslin and Auperin (2004), where a positive correlation between the expression profiles of StAR and P450scc was observed, suggesting a similar mechanism of transcriptional regulations for these two genes in teleosts. The different effects of 11-KT and $\mathrm{T}$ are generally explained by the possible aromatization of $\mathrm{T}$ to $\mathrm{E} 2$, that will subsequently reduce cellular levels of T (Lokman et al., 1998). However, a previous in vitro study by Mori et al. (2000) demonstrated an almost ignorable conversion of T to E2 in primary cultures of immature male rainbow trout hepatocytes. In addition, HPLC studies showed that $\mathrm{T}$ is metabolized mainly into testosterone-glucuronide and androstenedione in these cells (Cravedi et al., 1996). While our study demonstrates that 11-KT and T gave rise to different expression patterns of transcripts directly involved in steroidogenesis, additional studies are needed to determine the precise role of aromatizable and non-aromatizable androgens in the regulation of ovarian steroidogenic genes and proteins in teleosts.

\subsection{Histology and stereological analysis of the growth and development of cod oocytes}

The volume fractions occupied by oocytes of different developmental classes in the previtellogenic cod ovary were modulated after exposure to androgens. In general, both $11-\mathrm{KT}$ and $\mathrm{T}$ produced previtellogenic oocyte growth and development, with 11-KT comparatively being the strongest modulator. Relevant to small preantral follicles in mammals, that resemble fish previtellogenic oocytes (given that growth progresses slowly occurring both before and after puberty (Hsueh et al., 2000) and appearing to be mostly gonadotrophinindependent), androgens has been implicated in mammalian oogenesis (McGee, 2000). For example, growing preantral and small antral follicles were significantly increased in number, and granulosa and thecal cell proliferation increased in androgen treated rhesus monkey (Vendola et al., 1998). Similarly, testosterone-treated women or those suffering from androgen excess (polycystic ovarian syndrome, androgen-producing tumors) showed increased number of growing follicles (Vercellini et al., 1993). Some of these effects may be indirect via surrounding stromal tissue (Vendola et al., 1999). Direct androgen effects on ovarian follicles are very likely since androgen receptor (AR) mRNA abundance in rhesus monkey was highest in preantral to small 
antral follicles (Weil et al., 1998). Androgens also modify the intraovarian gene expression in the rhesus monkey, as demonstrated by increased mRNA abundance of insulin-like growth factor-1 (IGF-1) and IGF-1-receptor (Vendola et al., 1999) in follicles up to early antral stage. Except for the evidence that androgens increase oocyte "diameter" and modify growth factor mRNA abundance, the underlying molecular mechanism(s) involved in possible gene regulation resulting in the growth of previtellogenic oocytes has not been investigated, and have been addressed in the present study.

The present study shows a consistent stereological validation of oocyte growth and development after exposure to androgens. Tissues exposed to 11-KT and T showed significantly higher volume fractions of previtellogenic oocytes of advanced growth as compared to the solvent control. A second stereological approach was employed in the present study in order to investigate the mean volume of previtellogenic oocytes of different developmental classes. This method is referred to as the Point Sampled Intercept (PSI), and allows an unbiased estimation of the mean volume and variability of particles of arbitrary shape (Gundersen and Jensen, 1985). PSI analysis of cod previtellogenic ovary tissues exposed to 11-KT and T showed similar patterns as observed by the previous discussed method of volume fractions, demonstrating an apparent increase in oocyte volume after androgen exposure (data not shown). All stereological studies require representative sampling of the organ and generation of adequate sectioning of the structures to be analyzed (Mandarim-de-Lacerda, 2003). The sampling and arbitrary sectioning of the (naturally roundish) oocytes granted the isotropy requirements (Mandarimde-Lacerda, 2003). Also, previous studies have shown that oocyte size distribution is homogenous in cod ovaries (Kjesbu and Holm, 1994). Finally, all the gonadal tissues examined in the present study displayed a normal histology. The volume densities of atretic oocytes were generally $3-5 \%$, showing no significant differences between control and androgen exposed tissues. Although it has been shown that atresia occurs in oocyte of all developmental classes, very little is known about atresia during early stages of oocyte development (Tyler and Sumpter, 1996). Oocyte areas with a high density of spermatozoa were observed at both day 5 and day 10 of exposure for tissues exposed to 11-KT and T, with higher volume fractions observed in tissues exposed to 11-KT compared to tissues exposed to T. The appearance of spermatozoa in cultivated ovarian tissue is puzzling, and the possibility that sex reversal was occurring in cultivated ovarian tissue exposed to androgens should not be excluded. If sex reversal was occurring within 5 days of in vitro androgen exposure, one would think that less mature stages of male germ cells (i.e. spermatogonia and spermatocytes) could be observed at earlier time points, at least in some sections. However, it should also be noted that not all androgen exposed ovary tissue samples examined contained spermatozoa. Previous studies addressing the effects of $11-\mathrm{KT}$ on previtellogenic ovarian growth have demonstrated the presence of male germ cells in androgen treated female fish in vivo (Rohr et al., 2001) but not in vitro (Lokman et al., 2007).

\subsection{Evaluation of in vitro floating agarose method}

From an endocrine and reproductive physiology point of view, these findings represent an interesting aspect of the role of androgens on previtellogenic oocyte growth in teleosts. However, we do acknowledge that the nominal 11-KT and T concentrations (10 and $100 \mu \mathrm{M}$ ) used in the present study are several orders of magnitude higher than physiological androgen levels reported in fish. In the present study, plasma levels of 11-KT in the female fish used for the in vitro gonadal incubation was $1 \pm 0.5 \mathrm{ng} / \mathrm{ml}$ of $n=4$ individuals. To our knowledge, there are no previous studies that have measured physiological androgen levels in previtellogenic stages of cod, although a few studies have measured variable T levels in cod during later stages of oocyte development (Dahle et al., 2003; Kjesbu et al., 1996). In a study by Lokman et al. (2002), it was demonstrated that the presence of both 11-KT and $\mathrm{T}$ in females for a number of teleost species were generally at low concentrations $(<1 \mathrm{ng} / \mathrm{ml})$. In planning and designing this study, we hypothesized that only a fraction of the given androgen concentrations will be accessible to the oocytes using the in vitro floating agarose method after considering biological factors such as bioavailability and bioconcentration. This hypothesis was supported by EIA analyses of 11-KT concentration in tissue cultures used in the present study (see Fig. 8). Solvent control tissues displayed a mean 11KT concentration of $0.68 \mathrm{ng} / \mathrm{mg}$ tissue (wet weight), whereas mean 11KT concentration increased 10 and 30-fold when exposed to 11-KT at the nominal concentrations of 10 and $100 \mu \mathrm{M}$, respectively. These measurements were conducted $24 \mathrm{~h}$ post-exposure, and steroid concentrations probably decreased rapidly during the next 4 exposure days, before fresh media with 11-KT was added to the cultures (i.e. at day 5). A rapid decrease in plasma steroid hormone levels has been reported previously during in vivo steroid injection of fathead minnow (Korte et al., 2000; Pakdel et al., 1991). Thus, we estimate that the low androgen concentration used in the present study $(10 \mu \mathrm{M})$ represents a physiological relevant concentration, whereas the high concentration $(100 \mu \mathrm{M})$ probably represents an extreme in vivo situation.

Furthermore, in a separate study using 1 and $1000 \mu \mathrm{M} 11-\mathrm{KT}$ and T (i.e. one magnitude lower and higher of the concentrations used in the present study), we found very modest differences in the studied variables (Kortner et al. unpublished). In addition, quantitative histological analyses showed a consistent stereological validation of oocyte growth after exposure to androgens both when exposed to 10 and $100 \mu \mathrm{M}$ (this study) or 1 and $1000 \mu \mathrm{M}$ (Kortner et al. unpublished). The modest differences between androgen concentrations observed in our studies may be explained by the fact that steroid hormone effects on cellular processes are regulated by auto-regulatory mechanisms and functional alterations will occur when threshold levels are reached irrespective of administered concentration. This assumption is further supported by the fact that histological analyses of all tissues did not show any toxicity related differences between control and 11-KT or T exposed samples when exposed to $1,10,100$ or $1000 \mu \mathrm{M}$. In accordance, previous in vitro studies have used comparable androgen concentrations used in the present study (Braun and Thomas, 2003; Mori et al., 1998). Nevertheless, an in vitro system lacks the absolute metabolic competence of an intact organism and our finding does not directly reflect an in vivo condition. However, the findings in the present study represent some novel aspects of the roles of androgens on the early growth of previtellogenic oocytes that recently has been validated in vivo in our laboratory using physiological androgen levels (Kortner et al. in preparation).

\section{Conclusions}

The present study provides the identification, sequencing and the expression patterns of a number of androgen-responsive genes in the previtellogenic cod ovary. We present the first targeted cod array (CodArray), consisting of clones with unique expression patterns that were either up- or down-regulated after androgen exposure using an in vitro previtellogenic oocyte culture technique with subsequent SSH analysis. Quantitative real-time polymerase chain reactions demonstrated the changes in expression for selected genes that are believed to be involved in the growth and development of previtellogenic oocytes in the Atlantic cod. Furthermore, we show that androgens promote oocyte growth and development in cod previtellogenic gonadal tissues. We present a consistent stereological validation of oocyte growth and development after exposure to androgens. In general, both 11-KT and $\mathrm{T}$ are capable of inducing previtellogenic oocyte growth and development, with the former hormone being the strongest modulator. Although not conclusive, the demonstration of previtellogenic oocyte growth and development after androgen exposure and the related differential expression of a number of 
androgen-responsive genes reveal novel roles of androgens concerning the growth and development of previtellogenic oocytes, indicating androgen control of early follicular and oocyte growth in the cod ovary.

\section{Acknowledgements}

This study was financed by the Norwegian Research Council (NFR) contract number 165073/V40. We thank Vidar Beisvåg and Hallgeir Bergum at the Norwegian Microarray Consortium (NMC) for helpful discussions during the array printing process. We thank Prof. Atle Bones for letting us use the functional genomics (FUGE) Arabidopsis National Platform facilities and Tommy S. Jørstad for microarray analysis.

\section{Appendix A. Supplemental data}

Supplementary data associated with this article can be found, in the online version, at doi:10.1016/j.cbd.2008.04.001.

\section{References}

Abraham, M., Hilge, V., Lison, S., Tibika, H., 1984. The cellular envelope of oocytes in teleosts. Cell Tissue Res. 235, 403-410.

Aegerter, S., Jalabert, B., Bobe, J., 2004. Messenger RNA stockpile of cyclin B, insulin-like growth factor I, insulin-like growth factor II, insulin-like growth factor receptor Ib and p53 in the rainbow trout oocyte in relation with developmental competence. Mol. Reprod. Dev. 67, 127-135.

Arukwe, A., 2006. Toxicological housekeeping genes: do they really keep the house? Environ. Sci. Technol. 40, 7944-7949.

Arukwe, A., Goksøyr, A., 2003. Eggshell and egg yolk proteins in fish: hepatic proteins for the next generation: Oogenetic, population, and evolutionary implications of endocrine disruption. Comp. Hepatol. 2 (1), 4

Benjamini, Y., Hochberg, Y., 1995. Controlling the false discovery rate: A practical and powerful approach to multiple testing. J. R. Stat. Soc., Ser. B 47, 289-300.

Bieniarz, K., Kime, D.E., 1986. Autoradiographic localization of gonadotrophin receptors in ovaries of the common carp, Cyprinus carpio L. Gen. Comp. Endocrinol. 64, $151-156$

Borg, B., 1994. Androgens in teleost fishes. Comp. Biochem Physiol. C 109, 219-245.

Braun, A.M., Thomas, P., 2003. Androgens inhibit estradiol-17beta synthesis in Atlantic croaker (Micropogonias undulatus) ovaries by a nongenomic mechanism initiated at the cell surface. Biol. Reprod. 69, 1642-1650.

Bromage, N., Jones, J., Randall, C., Thrush, M., Davies, B., Springate, J., Duston, J., Barker, G., 1992. Broodstock management, fecundity, egg quality and the timing of egg production in the rainbow trout (Oncorhynchus mykiss). Aquaculture 100, 141-166.

Caussanel, C., Breuzet, M., 1977. [Hormonal control of the ovarian cycle in Labidura riparia (author's transl)]. Ann. Endocrinol. (Paris) 38, 403-404.

Chan, L., Means, A.R., O'Malley, B.W., 1978. Steroid hormone regulation of specific gene expression. Vitam. Horm. 36, 259-295.

Chang, Y.S., Hsu, C.C., Wang, S.C., Tsao, C.C., Huang, F.L., 1997. Molecular cloning, structural analysis, and expression of carp ZP2 gene. Mol. Reprod. Dev. 46, 258-267.

Cravedi, J.P., Paris, A., Monod, G., Devaux, A., Flouriot, G., Valotaire, Y., 1996. Maintenance of cytochrome P450 content and phase I and phase II enzyme activities in trout hepatocytes cultured as spheroidal aggregates. Comp. Biochem Physiol. C 113, 241-246.

Dahle, R., Taranger, G.L., Karlsen, O., Kjesbu, O.S., Norberg, B., 2003. Gonadal development and associated changes in liver size and sexual steroids during the reproductive cycle of captive male and female Atlantic cod (Gadus morhua L.) Comp. Biochem Physiol. A 136, 641-653.

Freere, R.H., Weibel, E.R., 1967. Stereological techniques in microscopy. J. R. Microsc. Soc. $87,25-34$.

Geslin, M., Auperin, B., 2004. Relationship between changes in mRNAs of the genes encoding steroidogenic acute regulatory protein and P450 cholesterol side chain cleavage in head kidney and plasma levels of cortisol in response to different kinds of acute stress in the rainbow trout (Oncorhynchus mykiss). Gen. Comp. Endocrinol. $135,70-80$

Goetz, F.W., Norberg, B., McCauley, L.A., Iliev, D.B., 2004. Characterization of the cod (Gadus morhua) steroidogenic acute regulatory protein (StAR) sheds light on StAR gene structure in fish. Comp. Biochem. Physiol. B. Biochem. Mol. Biol. 137, 351-362.

Goetz, F.W., McCauley, L.A., Goetz, G.W., Norberg, B., 2006. Using global genome approaches to address problems in cod mariculture. ICES J. Mar. Sci. 63, 393-399.

Gundersen, H.J., Jensen, E.B., 1985. Stereological estimation of the volume-weighted mean volume of arbitrary particles observed on random sections. J. Microsc. 138, 127-142.

Hagen, I.J., Kusakabe, M., Young, G., 2006. Effects of ACTH and cAMP on steroidogenic acute regulatory protein and $\mathrm{P} 450$ 11beta-hydroxylase messenger RNAs in rainbow trout interrenal cells: Relationship with in vitro cortisol production. Gen. Comp. Endocrinol. 145, 254-262.

Ho, S.M., Taylor, S., Callard, I.P., 1982. Effect of hypophysectomy and growth hormone on estrogen-induced vitellogenesis in the freshwater turtle, Chrysemys picta. Gen. Comp. Endocrinol. 48, 254-260.
Hsueh, A.J., McGee, E.A., Hayashi, M., Hsu, S.Y., 2000. Hormonal regulation of early follicle development in the rat ovary. Mol. Cell. Endocrinol. 163, 95-100.

Ikeuchi, T., Todo, T., Kobayashi, T., Nagahama, Y., 1999. cDNA cloning of a novel androgen receptor subtype. J. Biol. Chem. 274, 25205-25209.

Ji, W., Wright, M.B., Cai, L., Flament, A., Lindpaintner, K., 2002. Efficacy of SSH PCR in isolating differentially expressed genes. BMC Genomics 3 (1), 12

Kjesbu, O.S., Kryvi, H., 1989. Oogenesis in cod, Gadus morhua L., studied by light and electron microscopy. J. Fish. Biol. 34, 735-746.

Kjesbu, O.S., Holm, J.C., 1994. Oocyte recruitment in first-time spawning Atlantic cod (Gadus morhua) in relation to feeding regime. Can. J. Fish Aquat. Sci. 51, 1893-1898.

Kjesbu, O.S., Kryvi, H., Norberg, B., 1996. Oocyte size and structure in relation to blood plasma steroid hormones in individually monitored, spawning Atlantic cod. J. Fish. Biol. 49, 1197-1215.

Kondo, T., Yanagawa, T., Yoshida, N., Yamashita, M., 1997. Introduction of cyclin B induces activation of the maturation-promoting factor and breakdown of germinal vesicle in growing zebrafish oocytes unresponsive to the maturation-inducing hormone. Dev. Biol. 190, 142-152.

Kondo, T., Kotani, T., Yamashita, M., 2001. Dispersion of cyclin B mRNA aggregation is coupled with translational activation of the mRNA during zebrafish oocyte maturation. Dev. Biol. 229, 421-431.

Korte, J.J., Kahl, M.D., Jensen, K.M., Pasha, M.S., Parks, L.G., LeBlank, G.A., Ankley, G.T., 2000. Fathead minnow vitellogenin: complementary DNA sequence and messenger RNA and protein expression after 17B-estradiol treatment. Environ. Toxicol. Chem. 19, 972-981.

Kortner, T.M., Arukwe, A., 2007a. Effects of 17alpha-methyltestosterone exposure on steroidogenesis and cyclin-B mRNA expression in previtellogenic oocytes of Atlantic cod (Gadus morhua). Comp. Biochem. Physiol. C. Toxicol. Pharmacol. 146, $569-580$

Kortner, T.M., Arukwe, A., 2007b. The xenoestrogen, 4-nonylphenol, impaired steroidogenesis in previtellogenic oocyte culture of Atlantic cod (Gadus morhua) by targeting the StAR protein and P450scc expressions. Gen. Comp. Endocrinol. 150, 419-429.

Krone, P.H., Sass, J.B., Lele, Z., 1997. Heat shock protein gene expression during embryonic development of the zebrafish. Cell. Mol. Life Sci. 53, 122-129.

Krone, P.H., Evans, T.G., Blechinger, S.R., 2003. Heat shock gene expression and function during zebrafish embryogenesis. Semin. Cell Dev. Biol. 14, 267-274.

Leatherland, J.F., Copeland, P., Sumpter, J.P., Sonstegard, R.A., 1982. Hormonal control of gonadal maturation and development of secondary sexual characteristics in coho salmon, Oncorhynchus kisutch, from lakes Ontario, Erie, and Michigan. Gen. Comp. Endocrinol. 48, 196-204.

Lindquist, S., Craig, E.A., 1988. The heat-shock proteins. Annu. Rev. Genet. 22, 631-677.

Lokman, P.M., Vermeulen, G.J., Lambert, J.G.D., Young, G., 1998. Gonad histology and plasma steriod profiles in wild New Zealand freshwater eels (Anguilla dieffenbachii and $A$. australis) before and at the onset of the natural spawning migration. I. Females. Fish Physiol. Biochem. 19, 325-338.

Lokman, P.M., Harris, B., Kusakabe, M., Kime, D.E., Schulz, R.W., Adachi, S., Young, G. 2002. 11-Oxygenated androgens in female teleosts: prevalence, abundance, and life history implications. Gen. Comp. Endocrinol. 129, 1-12.

Lokman, P.M., George, K.A., Divers, S.L., Algie, M., Young, G., 2007.11-Ketotestosterone and IGF-I increase the size of previtellogenic oocytes from shortfinned eel, Anguilla australis, in vitro. Reproduction 133, 955-967.

Luckenbach, J.A., Iliev, D.B., Goetz, F.W., Swanson, P., 2008. Identification of differentially expressed ovarian genes during primary and early secondary oocyte growth in coho salmon, Oncorhynchus kisutch. Reprod. Biol. Endocrinol. 6 (1), 2.

MacKenzie, D.S., VanPutte, C.M., Leiner, K.A., 1998. Nutrient regulation of endocrine function in fish. Aquaculture 161, 3-25.

Mandarim-de-Lacerda, C.A., 2003. Stereological tools in biomedical research. An. Acad. Bras. Cienc. 75, 469-486.

McGee, E.A., 2000. The regulation of apoptosis in preantral ovarian follicles. Biol. Signals Recept. 9, 81-86.

Miura, T., Kudo, N., Miura, C., Yamauchi, K., Nagahama, Y., 1998. Two testicular cDNA clones suppressed by gonadotropin stimulation exhibit ZP2- and ZP3-like structures in Japanese eel. Mol. Reprod. Dev. 51, 235-242.

Modig, C., Modesto, T., Canario, A., Cerda, J., von Hofsten, J., Olsson, P.E., 2006. Molecular characterization and expression pattern of zona pellucida proteins in gilthead seabream (Sparus aurata). Biol. Reprod. 75, 717-725.

Modig, C., Westerlund, L., Olsson, P.E., 2007. Oocyte Zona pellucida proteins. In: Babin, P.J., Cerda, J., Lubzens, E. (Eds.), The Fish Oocyte: From Basic Studies to Biotechnological Applications. Springer, pp. 113-139.

Mommsen, T.P., Walsh, P.J., 1988. Vitellogenesis and oocyte assembly. Fish Physiol. 12A, 347-406.

Morel, G., Cavalier, A., 2001. In Situ Hybridization in Light Microscopy. CRC Press LLC, USA.

Morgan, D.O., 1995. Principles of CDK regulation. Nature 374 (6518), 131-134.

Mori, T., Matsumoto, H., Yokota, H., 1998. Androgen-induced vitellogenin gene expression in primary cultures of rainbow trout hepatocytes. J. Steroid Biochem. Mol. Biol. 67, 133-141.

Mori, T., Sumiya, S., Yokota, H., 2000. Electrostatic interactions of androgens and progesterone derivatives with rainbow trout estrogen receptor. J. Steroid Biochem. Mol. Biol. 75, 129-137.

Morimoto, R.I., Tissieres, A., Georgopoulos, C., 1994. The Biology of Heat Shock Proteins and Molecular Chaperones. Cold Spring Harbor Laboratory Press, New York.

Nagahama, Y., 1997. 17 alpha,20 beta-dihydroxy-4-pregnen-3-one, a maturationinducing hormone in fish oocytes: mechanisms of synthesis and action. Steroids 62, 190-196. 
Neuer, A., Spandorfer, S.D., Giraldo, P., Jeremias, J., Dieterle, S., Korneeva, I., Liu, H.C., Rosenwaks, Z., Witkin, S.S., 1999. Heat shock protein expression during gametogenesis and embryogenesis. Infect. Dis. Obstet. Gynecol. 7, 10-16.

Olsson, P.E., Berg, A.H., von Hofsten, J., Grahn, B., Hellqvist, A., Larsson, A., Karlsson, J., Modig, C., Borg, B., Thomas, P., 2005. Molecular cloning and characterization of a nuclear androgen receptor activated by 11-ketotestosterone. Reprod. Biol. Endocrinol. $3,37$.

Pakdel, F., Feon, S., Le Gac, F., Le Menn, F., Valotaire, Y., 1991. In vivo estrogen induction of hepatic estrogen receptor mRNA and correlation with vitellogenin mRNA in rainbow trout. Mol. Cell Endocrinol. 75, 205-212.

Pan, J., Sasanami, T., Kono, Y., Matsuda, T., Mori, M., 2001. Effects of testosterone on production of perivitelline membrane glycoprotein ZPC by granulosa cells of Japanese quail (Coturnix japonica). Biol. Reprod. 64, 310-316.

Pan, Y.S., Lee, Y.S., Lee, Y.L., Lee, W.C., Hsieh, S.Y., 2006. Differentially profiling the lowexpression transcriptomes of human hepatoma using a novel $\mathrm{SSH} /$ microarray approach. BMC Genomics 7, 131.

Rocha, M.J., Rocha, E., 2006. Morphofunctional aspects of reproduction from synchronous to asynchronous fishes-an overview. In: Reinecke, M., Zaccone, G. Kapoor, B.G. (Eds.), Fish Endocrinol. 571-624.

Rohr, D.H., Lokman, P.M., Davie, P.S., Young, G., 2001. 11-Ketotestosterone induces silvering-related changes in immature female short-finned eels, Anguilla australis. Comp. Biochem. Physiol. A 130, 701-714.

Rondeau, G., McClelland, M., Nguyen, T., Risques, R., Wang, Y., Judex, M., Cho, A.H., Welsh, J., 2005. Enhanced microarray performance using low complexity representations of the transcriptome. Nucleic Acids Res. 33 (11), e100.

Slater, C.H., Schreck, C.B., Swanson, P., 1994. Plasma profiles of the sex steroids and gonadotropins in maturing female spring chinook salmon (Oncorhynchus tshawytscha). Comp. Biochem. Physiol. A. 109, 167-175.

Smyth, G.K., 2004. Linear models and empirical bayes methods for assessing differential expression in microarray experiments. Stat. Appl. Genet. Mol. Biol. 3 Article3.

Sperry, T.S., Thomas, P., 1999a. Characterization of two nuclear androgen receptors in Atlantic croaker: Comparison of their biochemical properties and binding specificities. Endocrinology 140, 1602-1611.

Sperry, T.S., Thomas, P., 1999b. Identification of two nuclear androgen receptors in kelp bass (Paralabrax clathratus) and their binding affinities for xenobiotics: Comparison with Atlantic croaker (Micropogonias undulatus) androgen receptors. Biol. Reprod. 61, 1152-1161.

Sperry, T.S., Thomas, P., 2000. Androgen binding profiles of two distinct nuclear androgen receptors in Atlantic croaker (Micropogonias undulatus). J. Steroid Biochem. Mol. Biol. 73, 93-103.

Steele, B.K., Meyers, C., Ozbun, M.A., 2002. Variable expression of some "housekeeping" genes during human keratinocyte differentiation. Anal. Biochem. 307, 341-347.

Stocco, D.M., 2001. StAR protein and the regulation of steroid hormone biosynthesis. Annu. Rev. Physiol. 63, 193-213.

Stocco, D.M., Wang, X., Jo, Y., Manna, P.R., 2005. Multiple signaling pathways regulating steroidogenesis and steroidogenic acute regulatory protein expression: more complicated than we thought. Mol. Endocrinol. 19, 2647-2659.
Storey, J.D., 2002. A direct approach to false discovery rates. J. R. Stat. Soc., Ser. B 64, 479-498.

Takeo, J., Yamashita, S., 1999. Two distinct isoforms of cDNA encoding rainbow trout androgen receptors. J. Biol. Chem. 274, 5674-5680.

Todo, T., Ikeuchi, T., Kobayashi, T., Nagahama, Y., 1999. Fish androgen receptor: cDNA cloning, steroid activation of transcription in transfected mammalian cells, and tissue mRNA levels. Biochem. Biophys. Res. Commun. 254, 378-383.

Touhata, K., Kinoshita, M., Tokuda, Y., Toyohara, H., Sakaguchi, M., Yokoyama, Y, Yamashita, S., 1999. Sequence and expression of a cDNA encoding the red seabream androgen receptor. Biochim. Biophys. Acta 1450, 481-485.

Tyler, C.R., Sumpter, J.P., 1996. Oocyte growth and development in teleost. Rev. Fish Biol. Fish 6, 287-318.

Vang, S.H., Kortner, T.M., Arukwe, A., 2007. Steroidogenic acute regulatory (StAR) protein and cholesterol side-chain cleavage (P450scc) as molecular and cellular targets for 17alpha-ethynylestradiol in salmon previtellogenic oocytes. Chem. Res. Toxicol. 20, 1811-1819.

Vendola, K.A., Zhou, J., Adesanya, O.O., Weil, S.J., Bondy, C.A., 1998. Androgens stimulate early stages of follicular growth in the primate ovary. J. Clin. Invest. 101, 2622-2629.

Vendola, K., Zhou, J., Wang, J., Famuyiwa, O.A., Bievre, M., Bondy, C.A., 1999. Androgens promote oocyte insulin-like growth factor I expression and initiation of follicle development in the primate ovary. Biol. Reprod. 61, 353-357.

Vercellini, P., Parazzini, F., Bolis, G., Carinelli, S., Dindelli, M., Vendola, N., Luchini, L., Crosignani, P.G., 1993. Endometriosis and ovarian cancer. Am. J. Obstet. Gynecol. $169,181-182$.

von Schalburg, K.R., Rise, M.L., Brown, G.D., Davidson, W.S., Koop, B.F., 2005. A comprehensive survey of the genes involved in maturation and development of the rainbow trout ovary. Biol. Reprod. 72, 687-699.

Weibel, E.R., 1979. Stereological Methods, Practical Methods for Biological Morphometry. Academic Press, London, UK.

Weil, S.J., Vendola, K., Zhou, J., Adesanya, O.O., Wang, J., Okafor, J., Bondy, C.A., 1998 Androgen receptor gene expression in the primate ovary: cellular localization, regulation, and functional correlations. J. Clin. Endocrinol. Metab. 83, 2479-2485.

Weil, S., Vendola, K., Zhou, J., Bondy, C.A., 1999. Androgen and follicle-stimulating hormone interactions in primate ovarian follicle development. J. Clin. Endocrinol. Metab. 84, 2951-2956.

Yang, G.P. Ross, D.T, Kuang, W.W. Brown, P.O., Weigel, R. 1999. Combining SSH and cDNA microarrays for rapid identification of differentially expressed genes. Nucleic Acids Res. 27, 1517-1523.

Yang, Y.H., Dudoit, S., Luu, P., Speed, T.P., 2001. Normalization for cDNA microarray data In: Bittner, M.L., Chen, Y., Dorsel, A.N., Dougherty, E.R. (Eds.), Microarrays: Optical Technologies and Informatics, pp. 141-152.

Zeng, S., Gong, Z., 2002. Expressed sequence tag analysis of expression profiles of zebrafish testis and ovary. Gene 294, 45-53. 